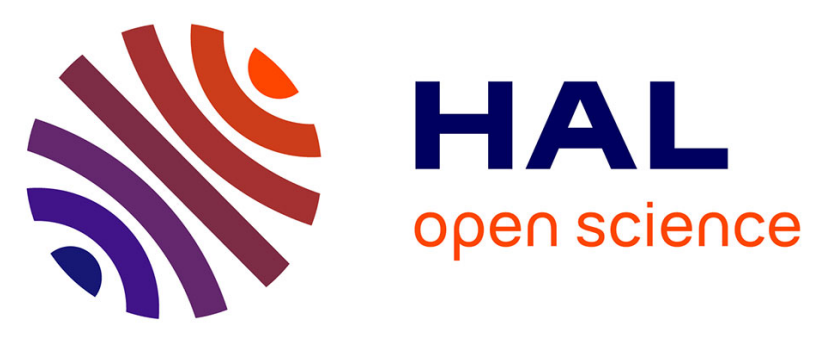

\title{
A quest for the lost types of Lophiotoma (Gastropoda: Conoidea: Turridae): integrative taxonomy in a nomenclatural mess
}

Nicolas Puillandre, Alexander E Fedosov, Paul Zaharias, Laetitia Aznar-Cormano, Yuri I Kantor

\section{To cite this version:}

Nicolas Puillandre, Alexander E Fedosov, Paul Zaharias, Laetitia Aznar-Cormano, Yuri I Kantor. A quest for the lost types of Lophiotoma (Gastropoda: Conoidea: Turridae): integrative taxonomy in a nomenclatural mess. Zoological Journal of the Linnean Society, 2017, 10.1093/zoolinnean/zlx012 . hal-02458219

\section{HAL Id: hal-02458219 \\ https://hal.science/hal-02458219}

Submitted on 28 Jan 2020

HAL is a multi-disciplinary open access archive for the deposit and dissemination of scientific research documents, whether they are published or not. The documents may come from teaching and research institutions in France or abroad, or from public or private research centers.
L'archive ouverte pluridisciplinaire HAL, est destinée au dépôt et à la diffusion de documents scientifiques de niveau recherche, publiés ou non, émanant des établissements d'enseignement et de recherche français ou étrangers, des laboratoires publics ou privés. 
1 A quest for the lost types of Lophiotoma (Gastropoda, Conoidea, Turridae): integrative 2 taxonomy in a nomenclatural mess.

3

4 NICOLAS PUILLANDRE ${ }^{1 *}$, ALEXANDER E. FEDOSOV $^{2}$, PAUL ZAHARIAS $^{1}$, 5 LAETITIA AZNAR-CORMANO ${ }^{1}$, YURI I. KANTOR ${ }^{2}$.

6

$7 \quad{ }^{1}$ Institut de Systématique, Évolution, Biodiversité ISYEB - UMR 7205 - CNRS,

8 MNHN, UPMC, EPHE, Muséum national d'Histoire naturelle, Sorbonne Universités, 957 rue Cuvier, CP26, F-75005, Paris, France

$10{ }^{2}$ A.N. Severtzov Institute of Ecology and Evolution, Russian Academy of Sciences,

11 Leninski prospect 33, 119071, Moscow, Russian Federation 12

Corresponding author: Nicolas Puillandre; Institut de Systématique, Évolution, Biodiversité ISYEB - UMR 7205 - CNRS, MNHN, UPMC, EPHE, Muséum national d’Histoire naturelle, Sorbonne Universités, 57 rue Cuvier, CP26, F-75005, Paris, France; +33 1407931 66; puillandre@mnhn.fr 
33

34

35

36

\section{Abstract}

Integrative taxonomy, and in particular species delimitation using molecular data, often lead to the discovery of new species. However, these new species are not systematically turned into formally described species, because, among other reasons, linking molecularly defined groups with available taxonomic names can be tricky. Here we delimit species in the genus Lophiotoma (Gastropoda, Conoidea, Turridae) using two unlinked genetic markers (the mitochondrial COI gene and the nuclear 28S gene), shell and radula characters, and geographic and bathymetric distribution. Several methods of species delimitation (ABGD, GMYC and PTP) resulted in several alternate species partitions, discussed using an integrative approach. We ended up with 10 different species, among which seven have been linked to available species names. We designated neotypes for two of them (L. acuta, L. jickelii). The three remaining species were described as new: L. semfala sp. n., L. bratasusa sp. n. and L. kina sp. n. We discuss the difficulties encountered to locate type specimens and link them to molecular species, in a context where the vast majority of mollusc types are empty, dried shells, difficultly accessible for molecular sequencing.

\section{Keywords}

Species delimitation, ABGD, GMYC, PTP, neotype designation, species description. 


\section{Introduction}

While DNA and integrative taxonomy (Dayrat, 2005; Will, Mishler, \& Wheeler, 2005) certainly participated in the revival of taxonomic research in the last 10 years, its impact on species descriptions remains limited. Most species descriptions are still based on morphological characters only (Pante, Schoelinck, \& Puillandre, 2014), and descriptions that include a molecular diagnosis remain scarce (Renner, 2016). In the Mollusca collection of the Museum National d'Histoire Naturelle (MNHN), Paris, the first holotype associated to a DNA sequence was registered in 2008; since then, 2,126 holotypes have been deposited in the MNHN collections, but only 65 are linked to a DNA sequence. As quoted by Bouchet \& Strong (2010), "80\% of the new species descriptions of shelled marine gastropod species published in 2006 contained a description of the shell only [i.e. without any mention of DNA characters, but also anatomy or radula]".

Why does the input of DNA characters remain so insignificant in the description of the biodiversity, in spite of its growing popularity among biologists? One of the reasons lies probably in the dichotomy between taxonomists (including amateurs, particularly active in molluscs) and “molecularists”, people who actually produce the DNA sequences. Most species remained described based on morphological characters because these characters still remain largely more accessible than DNA characters. Conversely, most molecularists are not trained in taxonomy and nomenclature, and many of the new species they discover, some of them being undetectable with morphological characters, remain undescribed, and thus virtually ignored by the scientific community (Goldstein \& DeSalle, 2011). Nevertheless, both approaches should be actually encouraged and applied synergistically: on the one hand, many species are difficult to distinguish morphologically, and in these cases integrative taxonomy, including DNA characters, proved its usefulness (Pante et al., 2015); on the other hand, linking molecularly defined species to available names, and eventually proposing new names, requires knowledge of the nomenclatural rules, of the taxonomic literature and, in particular, of the type specimens.

However, even close examination of the type material may be of little use in marine molluscs, as many name-bearing types simply do not fulfill their function, being too 
worn and badly preserved to confidently link the species name to other, more recently collected, material (Bouchet \& Strong, 2010). It is particularly true when several species share identical teleoconchs, differentiated only by protoconchs, radulae, anatomical or even DNA characters, as many of these characters are inaccessible on these types. Thus, a lost name-bearing type would actually be preferable, because in this case a procedure of neotype designation would be available, which would provide an ultimate solution to a species identity problem. This however, requires either a proof that the name-bearing types were lost, or application to the Commission of Zoological nomenclature, both being time consuming procedures.

To illustrate the benefit of a combination of molecularists and taxonomists, we applied an integrative taxonomy approach in a group of marine gastropods, Lophiotoma (Gastropoda, Conoidea, Turridae) that cumulates many of the difficulties listed above, plus some others, making it a good model to illustrate the link between species delimitation and species description: (i) because of their shell variability, several described species have been synonymized in the literature, and many names are potentially applicable; (ii) preliminary results published in Puillandre et al. (2012b) suggest that several MOTUs can share very similar shells; and (iii) type specimens of some species has been lost and are known by a figure only, and therefore are difficult to link to subsequently collected specimens. In this study, we apply the name Lophiotoma to the clade defined in Puillandre et al. (2012b) that includes the type-species L. acuta (Perry, 1811), but excluding other species sometimes referred as Lophiotoma (e.g. L. albina, L. indica), but not phylogenetically related to L. acuta. These shallow-water turrids, restricted to the Indo-Pacific, are known since the early 19th century. As most other conoideans, they are characterized by a venom apparatus, producing toxins used to capture their prey (most likely polychaetes). Their taxonomy has been revised by Powell (1964), and although they are regularly sampled by shell collectors, only one species (L. vezzaroi Cossignani, 2015) has been described since. To delimit species in this genus, we followed the general workflow of Puillandre et al. (2012b): species hypotheses are proposed in an integrative framework, based on a unified species concept in which species are considered as definitely diverging lineages (De Queiroz, 2007; Samadi \& Barberousse, 2009). First, Primary Species Hypotheses (PSH) were proposed using part of the mitochondrial COI gene and three of the most 
widely used methods based on monolocus data: ABGD (Automatic Barcode Gap Discovery, (Puillandre et al., 2012a)), GMYC (General Mixed Yule Coalescent model, (Pons et al., 2006; Monaghan et al., 2009)) and PTP (Poisson Tree Processes, (Zhang et al., 2013)). Second, monophyly of the PSH was tested performing Maximum Likelihood and Bayesian Analyzes on both COI and nuclear 28S genes, two unlinked genetic markers, to check whether each PSH corresponds to an independent lineage in both gene trees. Finally, morphological variability, and geographic and bathymetric distributions were integrated to turn the PSH into Secondary Species Hypotheses (SSH). In the final step, and after a deep search in the literature and in museum collections, available names were tentatively applied to the SSH, relying on shell characters and type localities; when no available name was found, the SSH was described as a new species.

\section{Material and Methods}

\section{Sampling}

The material was collected during several expeditions in the Indo-Pacific: Panglao 2004 and Aurora 2007 in the Philippines, Santo 2006 in Vanuatu, Inhaca 2011 in Mozambique, Nha-Trang in Viet-Nam (2010 - 2016) and Papua Niugini (2012) and Kavieng 2014 in Papua-New-Guinea (expeditions.mnhn.fr) (Fig. 1). All the material is stored in the MNHN.

Until 2012, live specimens for molecular analysis were anaesthetized with an isotonic solution of $\mathrm{MgCl}_{2}$ and fixed in $96 \%$ ethanol. Specimens collected during later expeditions were processed with a microwave oven (Galindo et al., 2014): the living molluscs in small volumes of sea water were exposed to microwaves for 7-30 seconds, depending on specimen size. Bodies were immediately removed from shells and dropped in 96\% ethanol. Specimens are registered in the MNHN collection and sequences were deposited in BOLD (Barcode of Life Datasystem) and GenBank (Supplementary Material 1).

DNA sequencing 
152 DNA was extracted using the Epmotion 5075 robot (Eppendorf), following the manufacturers' recommendations. A fragment of the cytochrome oxidase subunit I (COI) and of the rRNA 28S genes were amplified using universal primers LCO1490/HCO2198 (Folmer et al., 1994) and either C1/D3 (Jovelin \& Justine, 2001) or C2CONO (GAAAAGAACTTTGAAGAGAGAGT) / D3 (Ober, 2002), respectively. PCR reactions were performed in $25 \mu \mathrm{l}$, containing $3 \mathrm{ng}$ of DNA, 1X reaction buffer, $2.5 \mathrm{mM} \mathrm{MgCl}$, $0.26 \mathrm{mM}$ dNTP, $0.3 \mathrm{mM}$ of each primer, 5\% DMSO, and 1.5 units of Qbiogene Q-Bio Taq. For the COI fragment, amplification consisted of an initial denaturation step at $94^{\circ} \mathrm{C}$ for $4 \mathrm{~min}$, followed by 35 cycles of denaturation at $94^{\circ} \mathrm{C}$ for $30 \mathrm{~s}$, annealing at $50^{\circ} \mathrm{C}$ for $30 \mathrm{~s}$, followed by extension at $72^{\circ} \mathrm{C}$ for $1 \mathrm{~min}$. The final extension was at $72^{\circ} \mathrm{C}$ for $5 \mathrm{~min}$. The $28 \mathrm{~S}$ PCR reactions were performed in $20 \mu \mathrm{L}$ reaction volumes, containing a final concentration of $1 \mathrm{X}$ SsoAdvanced Universal SYBR Green Supermix, $0.3 \mathrm{mM}$ of primers, and $0.5 \mu \mathrm{g} / \mu \mathrm{L}$ of BSA, plus $1 \mu \mathrm{L}$ of DNA extract. The amplification thermal profiles consisted of an initial denaturation for 3 min at $94^{\circ} \mathrm{C}$, followed by 40 cycles of denaturation at $94^{\circ} \mathrm{C}$ for 30 s, annealing at $60^{\circ} \mathrm{C}$ for $30 \mathrm{~s}$, extension at $72^{\circ} \mathrm{C}$ for $1 \mathrm{~min}$ and a final extension at $72^{\circ} \mathrm{C}$ for $5 \mathrm{~min}$. PCR products were purified and sequenced by the Eurofins sequencing facility.

Species delimitation

COI sequences were aligned manually; 28S sequences were aligned using Muscle (Edgar, 2004) and alignments were checked by eye. Pairwise genetic distances (pdistances) were calculated using MEGA 6 (Tamura et al., 2013), following Srivathsan \& Meier (2012). ABGD, GMYC (both the single and multiple versions), PTP and the phylogenetic methods were applied to the COI and 28S alignments, plus a concatenation of the COI and 28S alignments (for a subset of specimens - see Results section). For ABGD, the web version (http://wwwabi.snv.jussieu.fr/public/abgd) and the default parameters were used, with a p-distance model. Bayesian trees were reconstructed using BEAST v1.8.3 (Drummond et al., 2012), running 100,000,000 (for the $28 \mathrm{~S}$ and COI+28S datasets) or 200,000,000 (for the COI dataset) generations with a sampling frequency each 4,000 generations. Relative divergence times were estimated 
using a relaxed lognormal clock with a coalescent prior and a constant population size, following the recommendations of Monaghan et al. (2009). Both single and multiple thresholds methods of GMYC were applied using the trees obtained with BEAST. Maximum likelihood trees, using RaxML v8.2.8 (Stamatakis, 2006), with the robustness of the nodes assessed using 1,000 bootstraps, and a Bayesian tree, using Mr.Bayes 3.2.6 (Huelsenbeck, Ronquist, \& Hall, 2001), were reconstructed. For the MrBayes analyses, each of the two runs consisted of six Markov chains and 20,000,000 generations, with 8 chains, 5 swaps at each generation, a sampling frequency of one tree each 2,000 generations and a chain temperature set at 0.02. For the Bayesian analyses (BEAST and MrBayes), convergence of each run was evaluated using TRACER 1.6 (Rambaut \& Drummond, 2014) to check that all effective sample size values exceeded 200. Consensus trees were calculated after omitting the first $25 \%$ trees as burn-in. All phylogenetic analyses were performed on the Cipres Science Gateway (http://www.phylo.org/portal2). In all cases, a GTR+I+G substitution model was used, and the COI gene was divided in three partitions corresponding to the three codon positions. For the concatenated datasets, four partitions were defined (3 codon positions of the COI and 28S gene). PTP was run with defaults parameters using the RAxML trees. Two specimens of closely related taxa were used as outgroups for phylogenetic analyses: Turris babylonia and Iotyrris musivum (Conoidea, Turridae).

\section{Shell morphology and radula}

Radulae were prepared by standard methods (Kantor \& Puillandre, 2012) and examined by scanning electron microscope TeScan TS5130MM in the Institute of Ecology and Evolution of Russian Academy of Sciences (IEE RAS). Protoconchs were measured in standard position and the number of whorls counted according to Bouchet \& Kantor (2004).

\section{Results}

Based on the partition with the highest number of PSH obtained with the COI gene, we build a reduced concatenated (COI+28S) dataset to limit computational time: 5 
specimens per PSH and per geographic regions maximum were kept. All the partitions obtained with ABGD, GMYC and PTP for the three datasets are shown in the Table 1. For the COI and COI+28S datasets, two partitions are discussed among the partitions proposed by ABGD: the partitions with the highest and lowest number of PSH (for the 28S dataset, only one partition was proposed by ABGD). The results of the GMYC "multiple" analyses are not shown, as well as the results of the GMYC "single” analysis for the 28S, because they proposed unrealistic number of PSH, not in agreement with the other methods, the phylogenetic trees and the other characters (111 PSH with the dataset COI for GMYC “multiple”, 27 for the COI+28S dataset for the GMYC "multiple”, and 79 and 78 for the 28S dataset for the GMYC "single” and "multiple", respectively). In all cases, the GMYC “multiple” partition was not significantly better than the GMYC "single" partition (p-value >> 0.05). The 28S gene is much less variable than the COI gene, and ABGD provided very few PSH with this gene (only five): this partition will be ignored in the rest of the text. In all the other cases, the number of PSH delimited varies from 8 to 16, all of them being compatible (i.e. they correspond to more or less inclusive PSH). In several cases, these splits correspond to a single specimen isolated from the others, in PSH including few specimens (less than five).

By comparing the PSH obtained with the different datasets (Table 1), the results of the phylogenetic analyses (Fig. 2 and 3), the morphological variation and the bathymetrical and geographical distributions (Supplementary Material 1), we turned the PSH in SSH and attributed available names to them or described them as new. Two PSH are found with all the genes and methods, have very distinct shells and are in our material restricted to a single archipelago: they were identified as L. polytropa, restricted to the Philippines, and L. vezzaroi, in Vanuatu. Those two PSH also always correspond to highly supported clades in the phylogenetic analyses. The PSH identified as $L$. abbreviata and L. brevicaudata, again with very distinct shells, are either found as a single PSH or as two different PSH (in one case - COI/PTP, L. abbreviata is divided in three groups, each corresponding to an unsupported clade). Their association generally corresponds to a highly supported clade. With the $28 \mathrm{~S}$ gene, L. abbreviata is monophyletic and (moderately) supported and L. brevicaudata is not monophyletic; it is the opposite with the COI gene, and with both genes both PSH are reciprocally 
monophyletic. Both are found in sympatry, sometimes even in the same station. It is the only species pair that seems to have distinct bathymetric preferences, $L$. abbreviata being found at average depth 2,9 $\mathrm{m}(+/-4 \mathrm{~m})$ and $L$. brevicaudata at 14,8 $\mathrm{m}$ deep (+/- 9 $\mathrm{m})$. One supported clade, found in Papua-New-Guinea and Vanuatu, is constantly defined as a separate PSH (except with 28S-PTP): L. bratasusa sp. n. It is morphologically very similar (see Taxonomy section), but distinguishable, to another PSH restricted to Papua-New-Guinea, sometimes co-occurring with it: L. picturata. The latter is sometimes separated in two PSH, morphologically undistinguishable and phylogenetically less supported (or even not recognized as monophyletic) than the whole PSH L. picturata. A similar situation is also found for a group of specimens with shell preliminarily identified as L. acuta. The first PSH, L. acuta, is abundant and widely distributed, and sometimes divided in two PSH. The second, L. semfala sp. n., contains fewer specimens, also widely distributed (Philippines, Papua-New-Guinea and Vanuatu), and once again is sometimes divided in two PSH. However, as for L. acuta and L. picturata, the support is lower for the subgroups. Finally, the two last PSH are also morphologically similar: L. jickelii and L. kina sp. n. Once again, there were sometimes separated in two PSH each, less supported than the more inclusive PSH. And as for L. picturata and L. bratasusa sp. n., L. semfala sp. n. and L. acuta on one hand, and L. jickelii and L. kina sp. n. on the other hand, are also found in sympatry, sometimes co-occurring at the same station.

\section{Taxonomy}

We provided descriptions for the new or newly defined taxa (as in case of neotype designation), and diagnosis for the species for which the status and scope do not change (compared to the generally accepted scope of the species). In addition to the type material, see the Supplementary Material 1 for the other material examined.
Abbreviations
BMNH: British Museum of Natural History, London, United Kingdom. MMM: Mostra Mondiale Malacologia. MHNG: Muséum d’Histoire naturelle, Geneva, Switzerland 
MNHN: Muséum National d'Histoire Naturelle, Paris, France.

SMF: Forschungsinstitut Senckenberg, Frankfurt, Germany.

ZMB: Museum für Naturkunde, Humboldt-Universität, Berlin, Germany.

\section{Superfamily CONOIDEA Fleming, 1822}

Family TURRIDAE H. \& A. Adams, 1853 (1838)

Genus Lophiotoma Casey, 1904

Type species. Pleurotoma acuta Perry, 1911, OD.

Diagnosis. Shell medium-sized to large, narrow to broad fusiform, with attenuated, usually long and nearly straight canal. Protoconch multispiral in examined in this respect species. Teleoconch whorls usually angulated at shoulder. Sculpture of sharp pronounced cords, including sinus area. Anal sinus deep, with nearly parallel sides. Operculum with apical nucleus.

Marginal radular teeth duplex. Anterior (inner) half is solid, narrow lanceolate, dorsoventrally compressed with sharp lateral cutting edges. In posterior half the major and accessory limbs bifurcate at the angle about $45^{\circ}$, rather thin. The central formation (sensu Kantor (2006)) is either absent or very weak, represented by central tooth, having shape of flat poorly developed cusp.

Remarks. The genus was revised by Powell (1964) who recognized two subgenera (nominative one and Lophioturris Powell, 1964) differing on the basis of the protoconch - multispiral in the former and blunt paucispiral in the latter. Powell attributed five Recent species to Lophiotoma s.s. As specified in the introduction, previous analyses revealed that among those included species Lophiotoma albina (Lamarck, 1822) should be excluded as it is more closely related to Gemmula-like species while on the contrary L. polytropa (Helbling, 1779) attributed by Powell to Lophioturris is confidently included in Lophiotoma on the basis of molecular analysis (Puillandre et al., 2012b). Protoconch of L. polytropa is unknown so far. Lophioturris with the type species Turris indica (Röding, 1798) is constituting a clade with Unedogemmula MacNeil, 1960 (type species Turris unedo Kiener, 1839-1840), not related to Lophiotoma as defined here, and thus becomes junior subjective synonym of the latter. Among species treated as Lophiotoma by Powell (1964) only one species, L. ruthveniana (Melvill, 1923) is absent 
in our material and its position remains unconfirmed. At the same time, recently described Lophiotoma vezzaroi Cosignani, 2015 was sequenced and falls within the Lophiotoma clade as defined here. This species was described from the Philippines and found by us in Santo; it is conchologically rather similar to L. ruthveniana.

\section{Lophiotoma acuta (Perry, 1811). (Fig. 4)}

Pleurotoma acuta Perry, 1811: pl. 5, fig. 5.

Pleurotoma marmorata Lamarck, 1816: pl. 439, fig. 6. (non Pleurotoma marmorata Link, 1807).

Pleurotoma tigrina Lamarck, 1822: 95 (nom. nov. pro Pleurotoma marmorata

Lamarck, 1816, non Pleurotoma marmorata Link, 1807).

Pleurotoma punctata Schubert \& Wagner, 1829: 155, pl. 234, figs 4103 a, b. (no locality).

Lophiotoma microsticta Casey, 1904: 130.

Lophiotoma acuta Perry, 1811 - Powell, 1964 (part.): 303-305, color plate 180, figs. 110, 15-18 (non plate 180), fig. 14, 19, nec

Type material. Neotype of Lophiotoma acuta (here designated), MNHN IM-200741179, the same specimen is designated as a neotype of Pleurotoma punctata (Schubert \& Wagner, 1829). Three syntypes of Pleurotoma tigrina, MHNG (MHNG-MOLL51664). Type locality: Indian Ocean, Madagascar coast. Syntypes of Lophiotoma microsticta, ?USNM (fide Powell (1964), see below). Type locality Cebu, Philippines. Type material of Pleurotoma (Turris) peaseana (Dunker, 1871), presumably lost (see below).

Type locality. Vanuatu, E Malo Island, $15^{\circ} 43,4^{\prime} \mathrm{S}, 16^{\circ} 15^{\prime} \mathrm{E}$, flat sand and dead corals, $6 \mathrm{~m}$ (Expedition SANTO 2006, st. DR84, R/V Aldric).

Material examined. 156 sequenced specimens (Supplementary Material 1). Description (neotype) (Fig. 4 A-D): Shell medium thick, narrow fusiform, with high spire and long narrow siphonal canal slightly inclined to the left. Protoconch (Fig. 4 D) conical, of nearly 3 evenly convex whorls, first whorls smooth, posteriormost half a whorl with 9 axial nearly straight riblets, more densely spaced in posterior part of protoconch. Protoconch diameter $0.78 \mathrm{~mm}$, height $0.85 \mathrm{~mm}$. Teleoconch whorls strongly angulated at shoulder, 10 in total. Suture shallow, subsutural region wide, 
distinctly concave, subsutural cord low, triangular in profile, with 3 weak angular ridges, central one strongest. Subsutural region smooth on upper teleoconch whorls, with one spiral ridge appearing on 4th, 2 on 6th, 3 on 7th and seven on the last whorl. Paired sinus cords strongest and form strong angulated shoulder. On upper whorls both cords are similar in size and rounded on top, on penultimate and last whorls cords are distinctly triangular in profile and upper much stronger than lower. Base of spire whorls smooth on first whorl, with one spiral cord on 2-6th whorls, starting from 7th whorl the number of cords gradually increases, and penultimate whorl with 6 narrow cords of slightly different size; interspaces 3-4 times broader than cords. Base of last whorl with 5 major spiral cords and several riblets between them, canal with 20 cords, becoming gradually broader, lower and more closely spaced anteriorly. Shell base gradually narrowing towards narrow and long nearly straight siphonal canal. Aperture pear shaped, outer lip concave in upper part and weakly convex below shoulder, gradually passing into canal. Anal sinus deep, with nearly parallel sides, its posterior margin straight, parallel to shell axis; outer lip in side-view rounded and opisthocline, stromboid notch ill-defined. Growth lines indistinct, closely spaced. Shell creamy, protoconch and two first teleoconch whorls light brown. Subsutural cord with regularly spaced brown spots, not extending beyond cord. Sinus cords with distinct dark brown regularly spaced spots occupying whole width of cord and separate on each cord, minor spiral cords with dense brown flecks. Aperture creamy inside. Measurements: SL 38.8 mm, AL (with canal) $19.7 \mathrm{~mm}$, SW $11.0 \mathrm{~mm}$. Radula was examined in five specimens, all from Papua New Guinea. It was very similar in all examined specimens (Fig. 5 AB). Radula membrane long, consists of 55-80 rows of teeth of which 25-30 are not fully formed. Marginal teeth duplex. Anterior (inner) half is solid, narrow lanceolate, dorsoventrally compressed with sharp lateral cutting edges. In posterior half the major and accessory limbs bifurcate at the angle about $45^{\circ}$, rather thin. The central formation is absent or very weak, in the form of flat poorly developed cusp, looking like folds of the membrane, but regularly positioned.

Remarks. The species is very variable in terms of coloration and shell shape. The base color can be from pure white to light orange and even light brown (subsutural region, shell base and canal) with lighter sinus area. With some reservation two color forms can be distinguished, although the intermediate specimens can also be found. In light form 
the brown spots are more scarce and usually confined to major cords, especially to subsutural and sinus ones, while the smaller cords have separate brown speckles. In dark form (Fig. $4 \mathrm{H}$ ) the entire shell can be light brown, with lighter band along the sinus cords. The large brown spots on subsutural cord dissolve in lower part into brown band, occupying entire subsutural zone. The brown spots on minor cords can be as large as those on sinus cords. The canal and anterior part of aperture can be also brownish. At the same time transitional specimens between forms can be found. The dark form was found within entire distribution area of the species. In Vanuatu, which is most rich in sequenced material $66 \%$ of specimens were represented by light form, 24 by dark form and $10 \%$ can be attributed to intermediate forms (total number of checked specimens = 94). Rather distinct form is found in Vietnam and the Philippines (Fig. $4 \mathrm{~J}$ ) - the shells are large (can reach $51 \mathrm{~mm}$ in our material), relatively heavy and with less pronounced sinus cord and the spots and speckles are rather fine, except those on subsutural cord. In the molecular tree based on COI they are sister to the rest of the Lophiotoma acuta, although do not form monophyletic group. The syntype of Lophiotoma microsticta Casey, 1904 (illustrated by Powell (1964): pl. 233, figs. 4-5), with SL $59.7 \mathrm{~mm}$ is rather similar to this form. Protoconchs were studied in eight specimens, are rather uniform, consist of 2.75 whorls. Number of 9 axial riblets varies from 6 to 11, protoconch height 0.88-0.95, diameter 0.8-0.83 mm. The species is most similar to L. semfala sp. $\mathrm{n}$. and some specimens can hardly be distinguished, nevertheless the morphology of the sinus cords seems to be rather uniform in L. acuta - on last whorl (in adult specimens) the upper cord is much more pronounced than the lower and has distinct triangular shape with sharp upper edge, while in $L$. semfala sp. n. the cords are nearly similar to each other and are more obtuse and rounded on top (Fig. 6).

Taxonomic remarks. The species was treated as broadly distributed and strongly variable. Powell (1964) listed a number of nominal taxa in the synonymy of this species, including Pleurotoma jickelii Weinkauff, 1875 and Pleurotoma picurata Weinkauff, 1876. On the basis of molecular and morphological analysis these two species appeared to be valid. Pleurotoma acuta Perry, 1811 was described without locality or shell measurements. Original shell illustration is a bit grotesque, although suitable for positive identification. Few existing types described by Perry (1811) are stored in the BMNH (Dance, 1986) and the type of P. acuta is not among them. Due to 
complicated taxonomic situation with the L. acuta complex, a neotype is here designated. The name Pleurotoma marmorata (non Pleurotoma marmorata Link, 1807 = Turris chaldea Kilburn, Fedosov \& Olivera, 2012) was listed by Lamarck (1816) (pl. 439, Fig. 6, Le Liste, p. 8). Later Lamarck (1822) (p. 95) renamed the species P. tigrina, citing his own figure, but still proposed the name Pleurotoma marmorata for another species, which became the homonym for the third time. Three syntypes of Pleurotoma tigrina are in MHNG (MHNG-MOLL-51664) (Fig. 4 F-G herein) and it is seemingly conspecific with L. acuta in our current understanding, being closer to the "dark" form. Judging from the syntypes of P. marmorata Lamarck, 1822 (MHNG-MOLL-51663) the species belong to the genus Unedogemmula MacNeil, 1961 and was listed in synonymy of Lophiotoma (Lophioturris) indica (Röding, 1798) by (Powell (1964). The syntype of Lophiotoma microsticta Casey, 1904 was illustrated by Powell (1964): pl. 233, figs. 45) and claimed to be deposited in USNM. Nevertheless we were not able to find it in the collections. Judging from the photo it has the same sculpture pattern as L. acuta, that is the dominating upper sinus cord; therefore we confirm the opinion of Powell (1964), that it is a synonym of L. acuta. Type material of Pleurotoma punctata was not traced despite queries in the corresponding museums and the original illustration is rather crude, although the general outline is similar to that of L. acuta. In order to fix the problem and to stabilize the nomenclature we designate the neotype of Pleurotoma acuta Perry, 1811 also as the neotype of $P$. punctata, thus the latter name is now a junior objective synonym of $P$. acuta. Pleurotoma peaseana (Dunker, 1871) (Pleurotoma (Turris) peaseana (Dunker, 1871): 154 (Indian Ocean)) is another species of doubtful affinity, which was synonymized by Powell (1964) with L. acuta. It was illustrated only in Weinkauff (1876, in (Weinkauff \& Kobelt, 1875-1887): 66, pl. 2, fig. 10) The illustration is depicting rather stout shell with moderately elongate canal, much shorter than in both $L$. acuta and L. semfala. The species may not be closely related to L. acuta. We were not able to trace the type despite queering museums, where the Dunker's type material can be stored. Powell (1964) synonymized the species with $L$. acuta without providing any arguments, the opinion being followed by Oyama (1966) and Higo, Callomon, \& Gotō (1999). Moreover, Weinkauff (1876, in (Weinkauff \& Kobelt, 1875-1887)) described the protoconch of peaseana consisting of 3 smooth semitranslucent whorls with poorly visible suture, not mentioning the characteristic 
axial ribs in posteriormost part of protoconch. This seems more similar to protoconch of Unedogemmula and we exclude the species from synonymy of L. acuta.

Distribution. Confirmed distribution of the species (based on sequenced specimens) tropical Indo-west Pacific (from Santo to Vietnam). Judging from the published data, it also includes Madagascar (type locality of tigrina), South Africa (Kilburn, 1983), Red Sea (Verbinnen \& Dirkx, 2007), Japan (Okutani, 2000), Fiji, Queensland (Australia) (Powell, 1964), New Caledonia (uncatalogued MNHN material).

\section{Lophiotoma semfala sp. n. (Fig. 7)}

Holotype. MNHN IM-2007-41337.

Type locality. Vanuatu, Aoré I. Aimbuei Bay, 15³2,8'S, $167^{\circ} 11,6^{\prime} \mathrm{E}$, white coral sand, 3-8 m (Expedition SANTO 2006, st. LD35, R/V Alis annex).

Other material. 5 sequenced specimens (Supplementary Material 1).

Etymology. semfala - the "same" in Bislama, the creole language, one of the official languages of Vanuatu. Used as noun in aposition to reflect the similarity to Lophiotoma acuta.

Description (holotype) (Fig. 7 A-D). Shell medium thick, narrow fusiform, with high spire and long narrow siphonal canal slightly inclined to the left. Protoconch conical, eroded, rendering exact whorl count and sculpture examination doubtful, of about 3 evenly convex whorls. Protoconch diameter $0.73 \mathrm{~mm}$, height $0.85 \mathrm{~mm}$. Teleoconch whorls angulated at shoulder, 10 in total. Suture very shallow, indistinct, subsutural region wide, distinctly concave, subsutural cord low, triangular in profile, with 3 angular ridges on last whorl, central one strongest. On upper teleoconch whorls only central ridge persists. Subsutural region smooth on upper teleoconch whorls, with one spiral ridge appearing on 4th, 2 on 6th, 3 on 7th and five on the last whorl. Paired sinus cords strongest and form angulated shoulder. On upper whorls both cords are nearly similar in size, obtusely triangular, on penultimate and last whorls cords are more angulate, although still rounded on top, only on last whorl the upper cord is distinctly stronger than lower. Base of spire whorls smooth on first four whorl, with one spiral cord on 5-6th whorls, starting from 7th whorl the number of cords gradually increases, and penultimate whorl with 7 narrow cords of slightly different size, median much stronger; interspaces 3-4 times broader than cords. Base of last whorl with 3 major 
471 spiral cords and several riblets between them, canal with 20 cords, becoming gradually

472 broader, lower and more closely spaced anteriorly. Shell base gradually narrowing

473 towards narrow and long nearly straight siphonal canal. Aperture pear shaped, outer lip

474 concave in upper part and weakly convex below shoulder, gradually passing into canal.

475 Anal sinus deep, with nearly parallel sides, its posterior margin straight, parallel to shell

476 axis; outer lip in side-view rounded and opisthocline, stromboid notch well defined.

477 Growth lines indistinct, closely spaced. Shell creamy, protoconch and three first

478 teleoconch whorls very light brown. Subsutural cord with regularly spaced brown spots, 479 not extending beyond cord, broader on last three whorls. Sinus cords with distinct dark 480 brown regularly spaced spots occupying whole width of cord and separate on each cord, 481 minor spiral cords with dense brown flecks. Aperture creamy inside. Measurements: SL $48241.8 \mathrm{~mm}$, AL (with canal) $20.9 \mathrm{~mm}$, SW $10.6 \mathrm{~mm}$. Radula was examined in three 483 specimens, two from Papua New Guinea and one from the Philippines. It was very 484 similar in all examined specimens (Fig. 6). Radula membrane medium long, consists of 485 33-50 rows of teeth of which 9-16 are not fully formed. Marginal teeth duplex. Anterior 486 (inner) half is solid, narrow lanceolate, dorso-ventrally compressed with sharp lateral 487 cutting edges. In posterior half the major and accessory limbs bifurcate at the angle 488 about $45^{\circ}$, rather thin. The central formation absent.

489 Remarks. The new species is represented only by 6 specimens, including the holotype 490 and despite the limited material, two rather distinct forms can be recognized. The "light" 491 form that includes the holotype has less brown spots and the base color is uniformly 492 creamy. The brown spots on subsutural cord are in most specimens confined to cord 493 itself and do not extend beyond, but in holotype on some whorls there are brownish 494 blurred extensions of the spots to subsutural region. Available specimens other than 495 holotype are smaller and less speckled. The "dark" form is represented by two 496 specimens only, one being juvenile (Fig. 7 F-G). It has slightly darker base color, with 497 light brown shell base and canal and with subsutural region below subsutural cord is 498 uniformly brown. There was not correlation between geographic distributions, since one 499 specimen of dark form was collected in the Philippines, while another in Papua New 500 Guinea at similar depths. The sinus cords of the adult specimen of the dark form are 501 also sharper on top on the last whorl. On most part of teleoconch whorls the sinus cords 502 are either similar in size, or the lower even slightly more pronounced, than the upper, 
only on the last whorl the situation changes to opposite. Intact protoconch persists only in the juvenile of the dark form (Fig. $7 \mathrm{G}$ ), it consists of 2.75 whorls, diameter $0.68 \mathrm{~mm}$, height 0.73 , that is significantly smaller than in holotype, although the existing material is insufficient for estimates of the variation. The species is extremely similar to Lophiotoma acuta, which also has dark and light forms. It can be distinguished in most cases by less pronounced and more rounded on top sinus cords, providing less angulated appearance to the shell shoulder, as well as more similar in size cords (Fig. 6, compare A-B with C-D), and domination of the lower cord over the higher one on teleoconch whorls. Protoconch of Lophiotoma acuta is slightly larger (Fig. 8), while the radula is longer (consists of 55-80 rows of teeth versus 33-50 rows in L. semfala).

Distribution. The species was found in the Philippines, Papua New Guinea and Santo. In all this localities it is sympatric with $L$. acuta. Judging from available material (only 6 sequenced specimens), it is much more rare than L. acuta, for which we had more than 160 specimens sequenced. Although we did not sequence any specimens from New Caledonia, judging from the shell characters the species is also found in New Caledonia (uncataloged MNHN material).

\section{Lophiotoma polytropa (Helbling, 1779) (Fig. 9E)}

Murex (Fusus) polytropus Helbling, 1779: 119, pl.2, figs 24, 25.

Pleurotoma fascialis Lamarck, 1822: 93; Kiener, 1840: 27, pl. 4, fig. 2.

Lophiotoma (Lophioturris) polytropa. - Powell, 1964: 313-314, pl. 244.

Lophiotoma polytropa. - Poppe, 2008: 770, pl. 680, fig. 4.

Lophioturris polytropa. - Lozouet \& Plaziat, 2008: 134, pl. 31, figs 5-9.

Type material. Whereabouts unknown.

Type locality. Not stated.

Material examined. 6 sequenced specimens (Supplementary Material 1).

Diagnosis. Shell medium-sized, exceeding $50 \mathrm{~mm}$, thick, turriform, with thick brown periostracum, shell dark-purplish brown. Sculpture of strong spiral elements, with rounded or angulate subsutural cord followed by notably elevated paired and broadly spaced sinus cords. Shell periphery and base with dense elevated cords, similar in size to sinus cords and with intermediate finer ridges. Siphonal canal medium long, nearly straight; aperture rather wide, purplish to greyish inside. Radula (Fig. 5 C) with duplex 
marginal teeth. Anterior (inner) half is solid, lanceolate, slightly asymmetrical, with nearly straight anterior margin and convex posterior margin, dorso-ventrally compressed with sharp lateral cutting edges. In posterior half the major and accessory limbs bifurcate at the angle about $45^{\circ}$, rather thin. Accessory limb is narrowing interiorly, where it fuses with major limb. The central formation absent.

Remarks. The species is rather distinct from all other congeners in having strong, tightly adhered periostracum and uniformly colored dark shell.

Taxonomic remarks. Pleurotoma fascialis (Lamarck, 1822), considered as a synonym of L. polytropa by Powell (1964), is morphologically different, and we exclude the species from synonymy of L. polytropa. Because the recognition of this species is not an issue, and even if we were not able to locate the types, we do not designate a neotype for $L$. polytropa.

Distribution. Powell (1964) recorded the species from the Philippines, Moluccas, New Britain and New Caledonia. The species is considered rare. Nevertheless, Lozouet \& Plaziat (2008) found it common in the mangrove environments of the lower estuary of the Abatan River (Bohol, Philippines). All the sequenced specimens originated from this locality. The species was successfully recollected several years later in the mentioned biotope (Kantor, Fedosov, unpublished).

\section{Lophiotoma abbreviata (Reeve, 1843) (Fig. 9 C-D)}

Pleurotoma abbreviata Reeve, 1843 (in 1843-1846): pl.10, fig. 86.

Lophiotoma abbreviata. - Powell, 1964: 309, pl. 237, 238, figs 1-2; Poppe (2008): pl. 683, fig. 5.

Type material. Lectotype (designated by Powell (1964) and 3 paralectotypes in BMNH.

Type locality. Masbate Island, Philippines, reefs at low tide. Material examined. 13 sequenced specimens (Supplementary Material 1).

Diagnosis. Shell small, turriform, with contrasting black spots on white background colour, and short siphonal canal, giving shell stout appearance. Sculpture of strong spiral elements, with rounded or angulate subsutural cord followed by notably elevated bisected sinus cord, and one fainter ridge on spire whorls. Shell base with dense elevated cords, sometimes interchanged by fine ridges. Microsculpture of dense very 
fine spiral treads throughout shell surface. Siphonal canal short and rather robust; aperture rather wide with moderately deep anal sinus. Inside of outer lip with distinct lirae.

Remarks. The small and robust-looking shell of L. abbreviata differs from notably more elongated, with long siphonal canal L. jickelii, L. vezzaroi, L. semfala and L. kina. In turn, the variegated color pattern readily distinguishes $L$. abbreviata from $\tan L$. brevicaudata and dark-brown L. polytropa. While being distinctive among congeners, L. abbreviata resembles small species of the genus Iotyrris, I. devoizei and I. kingae, primarily in colour pattern. However, both mentioned Iotyrris species have an even shorter siphonal canal, and thus proportionally much higher spire. Besides, the spiral elements are denser, and the whorl profile is less angulate, because of lower sinus cord in the Iotyrris species. Powell recognized in addition to nominotypical two subspecies L. abbreviata lifouensis (Sowerby, 1907) known only from Lifou, Loyalty Islands; and L. abbreviata ustulata (Reeve, 1846) with unknown type locality. The latter subspecies differs markedly in shell from the nominotypical one and its status remains unclear (as was suggested by Powell (1964). We also did not have specimens from Lifou available for sequencing and therefore the status of $L$. abbreviata lifouensis is still unresolved. Concerning the latter Cernohorsky (1972) claimed that the shells corresponding to both nominotypical and lifuensis subspecies were collected sympatrically in Fiji.

Distribution. Confirmed distribution of the species (based on sequenced specimens) is Papua New Guinea, New Caledonia and Santo. According to published data also found in the Philippines (Springsteen \& Leobrera, 1986) eastward to Fiji (Cernohorsky, 1972).

Lophiotoma brevicaudata (Reeve, 1843) (Fig. 9 A-B)

Pleurotoma brevicaudata Reeve, 1843 (in 1843-1846): pl.15, fig. 126.

Lophiotoma brevicaudata. - Powell, 1964: 406.

Type material. Lectotype and two paralectotypes in the BMNH (designated by Powell (1964)) (not illustrated).

Type locality. Ticao Island, Philippines, H. Cuming collection.

Material examined. 24 sequenced specimens (Supplementary Material 1).

Diagnosis: Shell small, turriform, with prominent spiral sculpture; spire coloured lightbrown or tan, siphonal canal dark-brown. Whorl outline indistinctly convex, as 
subsutural cord separated from succeeding cords by wide and deep depression. Sinus cord wide, composed of two ridges with rather shallow interspace, followed by two cords on whorl's base. Interspaces between cords sculptured by fine treads. Shell base convex, constricted to rather slender siphonal canal, sculptured with dense spiral to oblique cords. Aperture elongate, anal sinus moderately deep, wide, angulated at its tip. Outer aperture lip with white callus, distinctly lirate within.

Remarks. Lophiotoma brevicaudata is one of the easily recognizable species, primarily because of its characteristic color pattern with tan or light brown background color, and dark siphonal canal. Crests of spiral ridges are sometimes dark-brown as well. In particular, rather monotonous coloration of the spire readily sets $L$. brevicaudata apart from most closely related L. abbreviata. At the same time, L. brevicaudata is notably lighter, and in maturity smaller than L. polytropa. In addition to color pattern, a rather short siphonal canal, comparing to that in L. acuta, L. jickelii, L. vezzaroi, L. semfala and L. kina, allows rather straightforward identification of $L$. brevicaudata among congeners. Radula was examined in one sequenced specimen from Vanuatu (Fig. 5 D). Radula is very similar to other congeners, with duplex marginal teeth. Anterior (inner) half is solid, narrow lanceolate, dorso-ventrally compressed with sharp lateral cutting edges. In posterior half the major and accessory limbs bifurcate at the angle about $45^{\circ}$, rather thin. The central formation was not studied due to radula preparation. Distribution. Confirmed distribution of the species (based on sequenced specimens) is from Philippines to Vanuatu. According to MNHN material also New Caledonia.

\section{Lophiotoma picturata (Wienkauff, 1876) (Fig. 10)}

Pleurotoma picturata Weinkauff, 1876 in (Weinkauff \& Kobelt, 1875-1887): 66, pl. 2, fig. 10 .

Type material. Lectotype (here designated) ZMB Moll 112610, ex-Paetel collection, Philippines, SL 41 mm; paralectotype ZMB Moll 112610.

Type locality. Philippines (originally Indischer Ocean). Material examined. 8 sequenced specimens (Supplementary Material 1).

Diagnosis. Shell solid, narrow turriform, with high spire and moderately long siphonal canal. Protoconch of 3.75-4 slightly convex whorls; early 3 whorls smooth and glossy, latest whorl sculptured with 14-17 axial riblets (Fig. 10 E). Protoconch diameter 0.93- 
$1.12 \mathrm{~mm}$, height 1.13-1.25 mm. Teleoconch whorls distinctly angulated; adapical whorl portion between subsutural cord and sinus cord distinctly concave, sculptured with fine threads. Base of last adult whorl cylindrical, sculptured with 3-5 spiral threads. Shell base shortly constricted to slender siphonal canal. Shell base with 8-9 fine threads interchanging with sharp narrow spiral ridges, siphonal with 13-15 threads. Aperture elongate. Anal sinus wide and rather deep, quadrangular in its apex. Inside of aperture with 9-12 distinct lirae. Background colour cream, with distinct dark-brown spots on subsutural and sinus cords. Brown spots on subsutural cords surrounded by somehow nebulose lighter brown or reddish blotches. Shell base with indistinct light-brown band. Spiral threads with regular light-brown dots, protoconch light-brown; inside of aperture cream. Radula was examined in one sequenced specimen from New Ireland (MNHN IM-2013-53422, Fig. 5 E). Radula membrane long, of about 50 rows of teeth, of which 20 are not fully formed. Radula is very similar to other congeners, with duplex marginal teeth. Anterior (inner) half is solid, narrow lanceolate, dorso-ventrally compressed with sharp lateral cutting edges. In posterior half the major and accessory limbs bifurcate at the angle about $45^{\circ}$, rather thin. The central formation indistinct. Remarks. The species is represented in our material by eight specimens from North Papua and New Ireland, ranging in height from 24.5 to $32.1 \mathrm{~mm}$, showing modest variation in conchological characters. The only feature, which is found to vary notably, is the shape of anal sinus. It is moderately deep and wide with angulated outline in the specimen MNHN IM-2013-53422, and is even wider in the Wienkauff's type, collected from the Philippines. The sinus is U-shaped, and very deep in some other sequenced specimens. Despite no specimens of $L$. picturata from the Philippines were sequenced in the present study, we confidently apply the name to this clade of our molecular tree, based on conchological features that are shared by the studied type specimen from ZMB and sequenced specimens. No other specimens of L. picturata, mentioned by Wienkauff were studied. Since a morphologically close to L. picturata species L. bratasusa sp. n. was recognized in our analysis, in order to fix the identity of Lophiotoma picturata, we here designate the studied syntype ZMB Moll 112610 as a lectotype, therefore restricting the type locality as Philippines. Morphologically L. picturata is very close to the L. bratasusa; however, there are some minor, but rather stable characters, that allow unmistakable differentiation of the two species. Firstly, the two species differ in the 
number of protoconch whorls - the former species has a protoconch of 3.75-4 whorls, while the latter - with 3.25 whorls only. Correspondingly the diameter and height of the protoconchs are slightly larger in L. picturata (Fig. 8). Moreover, the inside of the aperture is lirate in all studied specimens of the L. picturata, and it is smooth in $L$. bratasusa. Shell proportions and colouration also offer some minute differences. The $L$. picturata, is more turriform in outline (due to comparatively shorter siphonal canal), and the black or dark brown spots on the subsutural region are surrounded by less contrasting light-brown or reddish blotches. On the contrary, L. bratasusa has a more fusiform outline, and the dark spots on the subsutural region are more contrasting in appearance. Weinkauff (1876) (in (Weinkauff \& Kobelt, 1875-1887)), when describing the species, cited Pleurotoma variegata sensu Reeve (1843), non Kiener (1840). The illustration of Reeve (1843): pl. 1 species 2) depicts the shell from the dorsal side which has a vague resemblance to $P$. picturata, although positive identification is hardly possible. Powell (1964) synonymized Pleurotoma picturata with Lophiotoma acuta and this viewpoint was accepted by subsequent authors.

Distribution. Confirmed distribution of the species (based on sequenced specimens) is Papua New Guinea. The species was described from the "Indian Ocean", so its range should be broader, but this needs confirmation.

\section{Lophiotoma bratasusa sp. n. (Fig. 10)}

Type material. Holotype MNHN IM-2013-51244, SL 26.0 mm; paratype 1, MNHN IM-2013-12566, paratype 2, MNHN IM-2013-53827.

Type locality. Papua New Guinea, Kavieng Lagoon, E of Kulinus I., Silver Sound, 0242,3'S, $150^{\circ} 39,1^{\prime} \mathrm{E}, 7-10 \mathrm{~m}$, coarse sand, coral patches (Expedition KAVIENG 2014, st. KR54).

Other material. 19 sequenced specimens (Supplementary Material 1). Etymology. bratasusa [pidgin] - sibling, refers to the revealed sister relationship between the new species and morphologically similar L. picturata. Description (holotype). Shell solid, narrow fusiform with high spire and rather long siphonal canal. Protoconch of 3.25 slightly convex whorls. Earlier 2.75 whorls smooth and glossy; latest 0.5 whorl sculptured with fine arcuate riblets, widely set at earlier portion and more dense at transition to teleoconch. Protoconch diameter $0.89 \mathrm{~mm}$, 
height 1,13 mm. Teleoconch of 9 angulated whorls, suture shallow and inconspicuous. Subsutural region distinctly concave; suture immediately bordered by fine thread, followed by typically low subsutural cord, and 3-7 regularly set spiral threads. Sinus cord bifurcated, formed by two subequal ridges on early whorls, whereas adapical ridge is notably stronger on penultimate and last teleoconch whorls. Abapical whorls portion (= whorls base) sculptured with four fine threads, fourth slightly stronger than preceding. Shell base shortly constricted to slender siphonal canal, sculpture of shell base of 11 fine threads, $4^{\text {th }}$ and $6^{\text {th }}$ elevated to form sharp spiral ridges. Siphonal canal sculptured with 15 threads, spirally oriented and widely set adapically and dense, weakly delineated from one-another and oblique towards canal's tip. Aperture elongate; outer aperture lip convex adapically, rounded in side view. Anal sinus typically deep and rather narrow with rounded apex. Inside of aperture typically smooth. Background colour cream, with distinct contrast dark-brown spots on subsutural and smaller dots on sinus cords. Spiral threads with regular light-brown dots, giving them appearance of dashed lines. Protoconch orange; inside of aperture cream. Radula (holotype) (Fig. 5 F) long, of about 55 rows of teeth, of which 25 are not fully formed. Radula is very similar to other congeners, with duplex marginal teeth. Anterior (inner) half is solid, narrow lanceolate, dorso-ventrally compressed with sharp lateral cutting edges. In posterior half the major and accessory limbs bifurcate at the angle about $45^{\circ}$, rather thin. The central formation absent.

Remarks. Lophiotoma bratasusa sp. n. shows a notable variation in shell shape, sculpture pattern and coloration. The two ridges of bisected sinus cord, may be equally strong, subequal, or differ notably, to the extent that the lower ridge is not stronger than succeeding spiral threads. Dark spots on the subsutural cord, typically well developed, may be lacking entirely, in light form (Fig. 10 L), or on the contrary the light brown band on the shell base may be pronounced, and tip of siphon canal colored dark-brown (Figs $10 \mathrm{~J}$ ). The species is undoubtedly closest to the $L$. picturata, although some differences between the two exist (see remarks under L. picturata), of which key are the number of protoconch whorls (4 in L. picturata 1 versus 3.25 in L. bratasusa) the color pattern on the subsutural cord (with extended lighter blotches in L. picturata 1 or without in L. bratasusa), and inside of the aperture (lirate in L. picturata VS smooth in L. bratasusa). 
Distribution. Confirmed distribution of the species (based on sequenced specimens) is Vanuatu and Papua New Guinea.

\section{Lophiotoma jickelii (Weinkauff, 1875) (Fig. 11)}

Pleurotoma jickelii Weinkauff, 1875 in (Weinkauff \& Kobelt, 1875-1887): 20, pl. 4, figs 2, 3 (Massaua, Red Sea).

Lophiotoma acuta form jickelii. - Powell, 1964: 305, pl. 180. figs 14, 19.

Type material. Neotype MNHN IM-2013-13275 (here designated). Type locality. Papua New Guinea, Tab Island, inner slope, 05²10,2'S, 14550,3'E (Expedition PAPUA NIUGINI, st. PR42).

Material examined. 33 sequenced specimens (Supplementary Material 1).

Description (neotype). Shell thin, fusiform (Fig. 11 A-C), with high spire and long narrow siphonal canal very slightly inclined to the left. Protoconch conical (Fig. 11 D), of about 3.75 evenly convex whorls, posteriormost 0.75 off a whorl before transition to teleoconch with 10 distinct arcuate, more closely spaced towards the transition to teleoconch. Protoconch diameter $1.0 \mathrm{~mm}$, height $1.22 \mathrm{~mm}$. Teleoconch whorls weakly angulated at shoulder, 10.5 in total. Suture moderately deep, distinct, subsutural region wide, distinctly concave, subsutural cord distinct, on upper 4 teleoconch whorls narrow, rounded on top, on 5th and lower whorls with two additional angular ridges appear in upper part of the cord, which becomes progressively stronger and on last whorl cord consists of three distinct sharp triangular in profile ridges, middle one most elevated. Subsutural region smooth on upper teleoconch whorls, with one spiral ridge appearing on 3rd whorl, two on the 4th, 3 on 5th, up to six on the last whorl. Paired sinus cords strongest, separated by interspace four times wider than cords, broadly obtuse triangular in profile and of the same strength on last whorl. On upper whorls both cords are similar in size, very closely spaced on upper four whorls and then become progressively broader spaced. Base of spire whorls smooth on upper two whorls, with one spiral cord on the 3-4th whorl, two on the 5th, and then fast enlarging in number up to 11, strongly different in size cords on penultimate whorl. Base of last whorl with 15 cords, 5 of which are much more prominent that the rest, canal with 34 cords, becoming gradually lower anteriorly. Cords are slightly nodulose on intersecting with growth lines. Shell base sharply narrowing towards narrow and long nearly straight siphonal canal. 
Aperture pear shaped, strongly constricted posteriorly, with parietal callus producing distinct tooth, outer lip concave in upper part and strongly convex below shoulder, gradually passing into canal. Anal sinus deep, narrow, with nearly parallel sides, its posterior margin nearly straight, parallel to shell axis; outer lip in side-view rounded and opisthocline, stromboid notch well-defined. Shell light brown, protoconch and two first teleoconch slightly darker. Subsutural cord(s) with light brown irregularly shaped spots. Sinus cords with narrow and irregularly spaced brown spots, well as minor spiral cords with spots sometimes having chevron shape and smaller flecks. Aperture light creamy, lirated deep inside. Measurements (neotype largest of our specimens): SL 39.4 mm, AL (with canal) 19.8 mm, SW 10.7 mm. Radula (neotype) (Fig. 5 G) long, of about 65 rows of teeth, of which 25 are not fully formed. Radula is similar to other congeners, with duplex somewhat stout marginal teeth. Anterior (inner) half is solid, lanceolate, dorso-ventrally compressed with sharp lateral cutting edges. In posterior half the major and accessory limbs bifurcate at the angle about $45^{\circ}$, rather thin. The central formation distinct, of small sharp narrow cusp.

Remarks. The species is rather variable in terms of sculpture and coloration. All intermediate specimens can be found from very light, hardly speckled specimens from Vietnam (Fig. $11 \mathrm{~K}$ ) to very dark ones from Mozambique, similar to the dark form of $L$. acuta (Fig. $11 \mathrm{~J}$ ). Interesting that the dark form was found only in Mozambique and the only two studied specimens from this region were dark. The degree of development of spiral cords (other than subsutural and sinus cords) can also be rather different - from fewer and similar in size 4 on subsutural zone to 6 strongly unequal in the neotype. What is similar in all studied specimens is that subsutural cord is distinctly "composite" consisting of 2 or even sometimes 3 lesser cords, that is clearly distinguish the species from any even very similarly colored specimens of L. acuta, in which the subsutural cord is distinctly single, while two much smaller additional ridges can run on it. There seems to be geographically determined shell variability (only dark forms in Mozambique and very light one in Vietnam), but very limited material from these mentioned localities does not allow us to draw final conclusions. The species was for long time considered as a synonym of L. acuta (eg. Powell (1964): p. 305 and many others), or as a Red Sea subspecies of the former. The name was used as a valid one recently for the specimens from Philippines (Heralde et al., 2007; Fedosov et al., 2011), 
but its validity was never addressed from the viewpoint of taxonomy. The types of Pleurotoma jickelii Weinkauff, 1875 originated from C. Jickeli collection, which is now partially stored in the Humboldt Museum, Berlin (http://www.conchology.be/?t=9001\&id=21727). Nevertheless, the types were not found in the Berlin Museum, nor in SMF, where the material of some other Weinkauff is kept. Therefore we consider them as presumably lost. The species was described from Massawa (presently Eritrea) based on beach collected specimen. The illustration of Weinkauff \& Kobelt (1875-1887): pl. 4, figs. 2, 3) is a bit ambiguous and depicts the large shell (SL $53 \mathrm{~mm}$ ) with poorly pronounced sinus cords and nearly straight sided bases of spire whorls, similar to those in our specimens. Powell (1964): pl. 180, fig. 19) illustrated the specimen of "form jickelii" from the Red Sea, very similar to ours and provided adequate and accurate description of Lophiotoma acuta form jickelii. Finally, Verbinnen \& Dirkx (2007) discussed the presence of Lophiotoma acuta and in Red Sea and the status of L. acuta jickelii (Weinkauff, 1875). They illustrated the shell of acuta (Fig. 21) as well as two shells, which represent L. jickelii (21a, 21b). We were able to examine one shell, collected in Egypt (Fig. 88 O) and it, as well as mentioned illustrated specimens, falls within intraspecific variability of a single species as defined herein by molecular data. In the absence of sequenced material from the Red Sea and due to confusing situation with the taxonomy of the species, we designate herein as the neotype of Lophiotoma jickelii, the specimen collected in Tab Island, Papua New Guinea, Madang Lagoon (Fig. $11 \mathrm{~A}-\mathrm{C}$ ). The species is most similar to Lophiotoma kina sp. n., found in Vanuatu and Papua New Guinea. For differences see the remarks for Lophiotoma kina sp. $\mathrm{n}$. The species can be readily distinguished from L. acuta in less pronounced subequal sinus cords rounded on top, while the upper sinus cord in L. acuta is much more pronounced, that the lower and both sinus cords has sharp upper edge. From both L. acuta and L. acuta 1 L. jickelii also differs in subsutural cord that is subdivided in several cords on last and penultimate whorls, while in the former it is uniform with sharp upper edge and very weak additional ridges. The studied radula of L. jickelii has broader anterior solid part of marginal teeth and more pronounced cusp of the central formation. 
Distribution. Confirmed distribution of the species (based on sequenced specimens) tropical Indo-west Pacific from Mozambique to Vietnam, Philippines, Papua New Guinea and Vanuatu. Basing on published data also the Red Sea.

\section{Lophiotoma kina sp. n. (Fig. 12)}

Type material. holotype MNHN IM-2013-16307, paratype MNHN IM-2013-13278. Type locality. Papua New Guinea, Madang Lagoon, W Tab Island, inner slope, 05¹0,1'S, $145^{\circ} 50,2^{\prime} \mathrm{E}, 3-6$ m (Expedition PAPUA NIUGINI, st. PR237).

\section{Other material. 3 sequenced specimens (Supplementary Material 1).}

Etymology. kina - the shell in Pidgin English, one of the official languages of Papua New Guinea. Used as noun in aposition.

Description (holotype). Shell medium thick, fusiform, with high spire and long narrow siphonal canal very slightly inclined to the left (Fig. 12 A-C). Protoconch (intact in the specimen MNHN IM-2013-12950) conical, eroded of about 2.75 evenly convex whorls, posteriormost half a whorl before transition to teleoconch with 9 axial riblets (Fig. 12 H). Protoconch diameter $0.88 \mathrm{~mm}$, height $0.93 \mathrm{~mm}$. Teleoconch whorls weakly angulated at shoulder, 9.5 in total. Suture shallow, subsutural region wide, distinctly concave, subsutural cord low, on upper teleoconch whorls on upper 5 whorls narrow, rounded on top, on 6th whorl additional angular ridge appear in upper part of the cord, which becomes progressively stronger and on last whorl cord consists of two distinct ridges, upper one being twice lower than the lower ridge. Subsutural region smooth on upper teleoconch whorls, with one spiral ridge appearing on 4th, 3 on 5th, 4 on 6 th and eight on the last whorl. Paired sinus cords strongest, separated by interspace three times wider than cords, obtuse triangular in profile and nearly of the same strength on last whorl. On upper whorls both cords are similar in size, with upper one being more pronounced on last and penultimate whorls. Base of spire whorls smooth on upper three whorls, with one spiral cord on the 4th whorl, two on the 5th, 3 on the 6th and 7 on penultimate. Base of last whorl with 3 major spiral cords and one two smaller ones between them, canal with 22 subequal cords, becoming gradually lower anteriorly. Shell base sharply narrowing towards narrow and long nearly straight siphonal canal. Aperture pear shaped, strongly constricted posteriorly with parietal callus producing distinct tooth, outer lip concave in upper part and weakly convex below shoulder, 
gradually passing into canal. Anal sinus deep, V-shaped, its posterior margin nearly straight, parallel to shell axis; outer lip in side-view rounded and opisthocline, stromboid notch well-defined. Growth lines indistinct, closely spaced. Shell light creamy, protoconch and three first teleoconch slightly darker. Subsutural cord(s) with light brown irregularly shaped spots. Sinus cords with very weak light brown regularly spaced flecks, as well as minor spiral cords and spots occupying whole width of cord and separate on each cord, minor spiral cords. Aperture light creamy, lirated deep inside. Measurements (holotype largest specimen): SL $31.0 \mathrm{~mm}$, AL (with canal) 15.7 mm, SW 9.3 mm. Radula (Fig. 5 I) is similar to other congeners, with duplex marginal teeth. Anterior (inner) half is solid, narrow lanceolate, dorso-ventrally compressed with sharp lateral cutting edges. In posterior half the major and accessory limbs bifurcate at the angle about $45^{\circ}$, rather thin. The central formation was not examined due to radula preparation.

Remarks. The species is most similar to L. jickelii and can be distinguished in more pronounced sinus cords and correspondingly more angulated whorls, generally less intensively colored shell, with only very weak brown flecks on the sinus cords and other spiral elements. It has also smaller protoconch (although protoconch was available only for 3 specimens), consisting of 2.75-3 whorls in kina versus 3.5-4.0 in jickelii (3.75 in most specimens) (Fig. 8).

Distribution. Confirmed distribution of the species (based on sequenced specimens) is Vanuatu and Papua New Guinea.

\section{Lophiotoma vezzaroi Cossignani, 2015 (Fig. 9 F-G)}

Lophiotoma abbreviata. - Okutani, 2000: pl. 313, fig. 54 (not of Reeve, 1843).

Lophiotoma cf. ruthveniana Melvill, 1923. - Poppe, 2008: pl. 683, fig. 4.

Lophiotoma vezzaroi Cossignani, 2015: 30-31, text figs.

$$
\text { Type material. Holotype MMM - Cupra Marittima. }
$$

Type locality. New Place Birat Samal Island, Philippines. Tangle net at 100-200 m. Additional material examined: 1 spm, Tinina Balut Island, Philippines, tangle net at 100-200 m.

$$
\text { Material examined. } 3 \text { sequenced specimens (Supplementary Material 1). }
$$


Diagnosis. Shell medium sized (up to $39 \mathrm{~mm}$ ), turriform, with prominent spiral sculpture; shell coloured with dense irregularly shaped brown to dark brown spots, siphonal canal off-white to tan. Whorl outline moderately convex, angulated at sinus. Sinus cords paired, subequal in size, with narrow interspace. Subsutural ramp and shell base sculptured with varying in width and prominence cords and finer riblets. Shell base convex, strongly constricted to rather slender siphonal canal, sculptured with dense spiral to oblique cords. Aperture elongate, anal sinus moderately deep, wide, angulated at its tip. Aperture distinctly lirate inside. Radula was examined in one poorly preserved specimen from Tinina Balut Island (Fig. 9 G). It is in all respects similar to other studied herein species of Lophiotoma.

Remarks. The species was confused previously with Lophiotoma ruthveniana. (Okutani, 2000) illustrated very similar specimen as Lophiotoma abbreviata. Although described from the Philippines our material and record of Okutani suggest its distribution from Japan to Papua New Guinea from 10-15 to more than 100 m.

Distribution. Vanuatu (sequenced specimens), Japan, Philippines and Papua New Guinea.

\section{Discussion}

Following an integrative taxonomy approach, we applied several criteria and methods of species delimitation to identify species boundaries within Lophiotoma. The three exploratory methods used (ABGD, GMYC and PTP) do not always agree on the species delimitation, but the use of other criteria and characters allowed choosing among the alternative species partitions the most robustly supported: the $10 \mathrm{SSH}$ retained are recognized as genetically (based on both distances and phylogenetic relationships) and morphologically distinct. The GMYC multiple method tends to oversplit, as was found e.g. by Kekkonen \& Hebert (2014). On the contrary, genes less variable than COI, such as the 28S, tend to cluster some species.

Among the ten delimited species, species in three pairs (L. acuta - L. semfala, $L$. picturata - L. bratasusa, and L. jickelii - L. kina) are hardly distinguishable morphologically: without molecular evidence they would hardly be suspected to be separate species. Moreover, the intraspecific morphological variability exceeds 
interspecific one, particularly in the shell coloration, with the presence of "light" and "dark" forms within each species of the pairs L. acuta - L. semfala and L. jickelii - L. kina. The radular characters that sometimes can be useful for species delimitation (Kantor et al., 2008) were of no help in the case of Lophiotoma. All examined species had extremely similar radular morphology and only in one species, L. jickelii, the radula had the central formation in the shape of a weak but distinct cusp, while in all others it was either absent, or indistinct. However, we confidently recognize them as distinct species, because (i) both genes recognized them as distinct clades, (ii) only in two cases (with the COI gene for L. picturata and L. bratasusa and with the 28S gene for L. acuta and L. semfala) they are found as sister species, and (iii) remarkably, morphologically similar species always occur sympatrically, which tends to support the hypothesis that they do not exchange genes.

The integrative taxonomy approach followed here was thus efficient to propose robust species hypotheses. It represents one additional example of the value of molecular characters when species can hardly be distinguished morphologically, a common situation in gastropods, and in particular in conoideans (e.g. (Duda et al., 2008; Puillandre et al., 2010; Jörger \& Schrödl, 2013). However, if proposing putative species using DNA sequences is now common, linking the SSH to available names, most often attached to non-sequenced specimens, remains problematic. Until now, all the species of Lophiotoma were described using conchological characters only. Moreover, locating type specimens to tentatively attribute their associated names to the defined SSH, based on morphological resemblance, was probably the most difficult task. Among the seven species already described before the present work, the type material was located for four species only (L. abbreviata, L. brevicaudata, L. picturata and L. vezzaroi). For $L$. vezzaroi, the holotype was properly designated, and for $L$. abbreviata and $L$. brevicaudata lectotypes (and paralectotypes) were designated in previous studies. For the last one, L. picturata, we located the syntypes and designated one lectotype and one paralectotype. For the three other species, L. acuta, L. jickelii and L. polytropa, we were unable to locate the type material (see details in the taxonomic section). In the absence of type material, we had to rely on the illustrations in the original descriptions to link the SSH to these names. For L. acuta and L. jickelii, because these names are associated to species complexes that include morphologically similar species, we choose one of the 
sequenced specimens in each species as a neotype. We also examined, when possible, the type material and/or the original illustrations of the species synonymized with $L$. acuta in the literature, and concluded that none of these names can confidently be attributed to one of the three remaining SSH. Consequently, we described these three SSH as new species: L. semfala sp. n., L. bratasusa sp. n. and L. kina sp. n. More generally, most species of molluscs were described before the molecular revolution, and the identity of most newly described species still remain based on dry material and/or non-sequenced specimens (Bouchet \& Strong, 2010). When dealing with species complexes, attributing names to molecular groups is thus tricky. When the type specimens are lost, designating a sequenced specimens as a neotype solve the problem. However, when the types are still available, morphological resemblance can be used to decide to which of the molecular groups the name will be attributed. We applied this strategy for the two species Xenuroturris legitima Iredale, 1929 and Iotyrris cingulifera (Lamarck, 1822) (Kantor et al., 2008): molecular studies and radula analyses revealed the presence of two very similar conchologically species. The types of the two mentioned names persist, both as empty shells, badly worn in the case of the Lamark's syntypes, and shell similarity helped to attribute each name to one of the two molecular groups. This solution was practical, because it allowed a stabilization of the nomenclature without the designation of neotypes, which in case of persisting types requires lengthy consideration by the Commission of Zoological Nomenclature. Here we used the same approach for L. picturata: we applied the name picturata to the species that was morphologically more similar to the lectotype. Because type specimens remain the only way to unambiguously link names and genetic groups, one could suggest that sequencing type-specimens, when available, is the ultimate solution. Traditionally, shell-bearing molluscs types are kept dried in collections, which does not ensure a correct DNA conservation. Recently developed

974 NGS techniques would clearly help to sequence fragmented DNA, but a high proportion of name-bearing types are empty shells, i.e. the shell does not contain the animal inside, even dried. Recently published articles (Geist, Wunderlich, \& Kuehn, 2008; Andree \&

977 López, 2013; Villanea, Parent, \& Kemp, 2016) suggest that DNA can actually be extracted from shells, but whether such techniques are applicable to specimens kept dried for ten, or even hundreds, of years, and for which the periostractum is potentially 
absent, remains to be tested. It also implies that a piece of the shell (Andree \& López, 2013) of the holotype will be destroyed, a condition that will need to be accepted by museum curators.

In any case, providing DNA sequences should become a gold standard in species delimitation and description in groups where morphological characters are misleading, such as in Conoidea, to avoid erroneous species hypotheses based on shell characters only and to facilitate the attribution of names to genetic sequences in the future. Even if sequencing DNA from empty shells seem conceivable, it is difficult to imagine that all types of shelled molluscs will be sequenced in the future (for technical and financial reasons), and in most cases linking these names to molecular groups will be subject to controversy. Paraphrasing Marshall (1983), who said that "under absolutely no circumstances should further new species [of Triphoridae] be proposed unless a complete, unworn protoconch can be illustrated”, ideally, under absolutely no circumstances should further new species of turrids be proposed without any molecular data.

\section{Acknowledgments}

A large part of the molecular material in this paper originates from various shore-based expeditions and deep sea cruises, conducted respectively by MNHN (Panglao 2004, Aurora 2007, Inhaca 2011); by MNHN, Pro-Natura International (PNI) and Institut de Recherche pour le Développement (IRD) as part of the Our Planet Reviewed programme (Santo 2006, Papua Niugini, Kavieng 2014); and by MNHN and Institut de Recherche pour le Développement (IRD) as part of the Tropical Deep-Sea Benthos programme. In-country partners include the University of San Carlos, Cebu City; Maritime College, Luganville; Universidade Eduardo Mondlane, Maputo; University of Papua New Guinea, Port Moresby, and National Fisheries College, Kavieng. Funders and sponsors include the Total Foundation, Prince Albert II of Monaco Foundation, Stavros Niarchos Foundation, Richard Lounsbery Foundation, Vinci Entrepose Contracting, Fondation EDF, the Philippines Bureau of Fisheries and Aquatic Resources (BFAR), the French Ministry of Foreign Affairs, the French Fonds Pacifique and the Government of New Caledonia. All expeditions operated under the regulations 
1012

1013

1014

1015

1016

1017

1018

1019

1020

1021

1022

1023

1024

1025

1026

1027

1028

1029

1030

1031

1032

1033

1034

1035

1036

1037

1038

1039

1040

1041

1042

1043

1044

then in force in the countries in question and satisfy the conditions set by the Nagoya Protocol for access to genetical resources. Collection of material in Vietnam was supported by the Russian-Vietnamese Tropical Center. We are thankful to the staff of the Tropical Center for assistance in organization of the field sampling and loan of some laboratory equipment. We thank, among others, Virginie Héros, Philippe Maestrati, Barbara Buge, Julien Brisset and Gilberto Marani for their role in specimens processing during the expeditions and their help in curating the specimens. This project was partly supported by the Service de Systématique Moléculaire (UMS 2700 CNRS-MNHN) and by the CONOTAX project funded by the French ANR (grant number ANR-13-JSV70013-01), grant of the Russian Science Foundation (16-14-10118, PI Yu. Kantor).

\section{References}

Andree KB, López MA. 2013. Species identification from archived snail shells via genetic analysis: a method for DNA extraction from empty shells. Molluscan Research 33: $1-5$.

Bouchet P, Kantor YI. 2004. New Caledonia: The major centre of biodiversity for volutomitrid molluscs (Mollusca: Neogastropoda: Volutomitridae). Systematics and Biodiversity 1: 467-502.

Bouchet P, Strong E. 2010. Historical name-bearing types in marine molluscs: an impediment to biodiversity studies? In: Polaszek A, ed. Systema Naturae 250. London: CRC Press, 63-74.

Casey TL. 1904. Notes on the Pleurotomidae with description of some new genera and species. Academy of Science of St. Louis.

Cernohorsky WO. 1972. Marine shells of the Pacific. Pacific publications.

Cossignani T. 2015. Lophiotoma vezzaroi sp. nov. Malacologica MOSTRA Mondiale. Cupra Marittima 88: 30-31.

Dance SP. 1986. A history of shell collecting. Leiden: Brill and Backhuys.

Dayrat B. 2005. Towards integrative taxonomy. Biological Journal of the Linnean Society 85: 407-415.

De Queiroz K. 2007. Species concepts and species delimitation. Systematic Biology 56: 879-886. 
Drummond AJ, Suchard MA, Xie D, Rambaut A. 2012. Bayesian phylogenetics with BEAUti and the BEAST 1.7. Molecular biology and evolution 29: 1969-1973.

Duda TF Jr, Bolin MB, Meyer C, Kohn AJ. 2008. Hidden diversity in a hyperdiverse gastropod genus: discovery of previously unidentified members of a Conus species complex. Molecular Phylogenetics and Evolution 49: 867-876.

Dunker W. 1871. Mollusca nova Musei Godeffroy Hamburgensis. Malakozoologische Blätter 18: 150-175.

Edgar RC. 2004. MUSCLE: multiple sequence alignment with high accuracy and high throughput. Nucleic Acids Research 32: 1792-1797.

Fedosov A, Watkins M, Heralde III FM, Showers Corneli P, Concepcion GP, Olivera BM. 2011. Phylogeny of the genus Turris: Correlating molecular data with radular anatomy and shell morphology. Molecular Phylogenetics and Evolution 59: 263-270.

Folmer O, Black M, Hoeh W, Lutz R, Vrijenhoek R. 1994. DNA primers for amplification of mitochondrial cytochrome c oxidase subunit I from diverse metazoan invertebrates. Molecular Marine Biology and Biotechnology 3: 294-299.

Galindo LA, Puillandre N, Strong EE, Bouchet P. 2014. Using microwaves to prepare gastropods for DNA barcoding. Molecular Ecology Resources 14: 700-705.

Geist J, Wunderlich H, Kuehn R. 2008. Use of mollusc shells for DNA-based molecular analyses. Journal of Molluscan Studies 74: 337-343.

Goldstein PZ, DeSalle R. 2011. Integrating DNA barcode data and taxonomic practice: Determination, discovery, and description. Bioessays 33: 135-147.

Helbling S. 1779. Beyträge zur Kenntniß neuer und seltener Konchylien. Aus einigen Wienerischen Sammlungen. Gerle.

Heralde FM, Watkins M, Ownby JP, Bandyopadhyay PK, Santos AD, Concepcion GP, Olivera BM. 2007. Molecular phylogeny of some Indo-Pacific genera in the subfamily Turrinae H. Adams and A. Adams, 1853 (1838) (Gastropoda: Neogastropoda). Nautilus 121: $131-138$.

Higo S, Callomon P, Gotō Y. 1999. Catalogue and bibliography of the marine shell bearing mollusca of Japan: gastropoda, bivalvia, polyplacophora, scaphopoda. Elle Scientific.

Huelsenbeck JP, Ronquist F, Hall B. 2001. MrBayes: Bayesian inference of phylogeny. Bioinformatics 17: 754-755.

Jörger KM, Schrödl M. 2013. How to describe a cryptic species? Practical challenges of molecular taxonomy. Frontiers in Zoology 10: 59. 
Jovelin R, Justine JL. 2001. Phylogenetic relationships within the polyopisthocotylean monogeneans (Plathyhelminthes) inferred from partial 28S rDNA sequences. International Journal for Parasitology 31: 393-401.

Kantor YI. 2006. On the morphology and homology of the 'central tooth' in the radula of Turrinae (Conoidea: Turridae). Ruthenica 16: 47-52.

Kantor YI, Puillandre N. 2012. Evolution of the radular apparatus in Conoidea (Gastropoda: Neogastropoda) as inferred from a molecular phylogeny. Malacologia 55: 55-90.

Kantor YI, Puillandre N, Olivera BM, Bouchet P. 2008. Morphological proxies for taxonomic decision in turrids (Mollusca, Neogastropoda): a test of the value of shell and radula characters using molecular data. Zoological Science 25: 1156-1170.

Kekkonen M, Hebert PDN. 2014. DNA barcode-based delineation of putative species: efficient start for taxonomic workflows. Molecular Ecology Resources 14: 706-715.

Kiener L. 1840. Species general et iconographie des Coquilles vivantes Comprenant la Collection du Muséum d'Histoire Naturelle de Paris, Collection Lamarck, celle du Prince Masséna et les Découverts Récente des Voyageurs (Genre Pleurotome). Paris: Rousseau.

Kilburn RN. 1983. Turridae (Mollusca: Gastropoda) of southern Africa and Mozambique. Part 1. Subfamily Turrinae. Annals of the Natal Museum 25: 549-585.

Lamarck J de. 1816. Tableau encyclopédique et méthodique des trois règnes de la nature. Vingt troisième partie. Mollusques et polypes divers.

Lamarck JBPA. 1822. Histoire naturelle des animaux sans vertèbres. Editions Publibook.

Lozouet P, Plaziat JC. 2008. Mangrove environments and molluscs. Conchbooks, Hackenheim.

Marshall B. 1983. A revision of the recent Triphoridae of Southern Australia (Mollusca: Gastropoda). Australian museum.

Monaghan MT, Wild R, Elliot ., Fujisawa T, Balke M, Inward DJG, Lees DC, Ranaivosolo R, Eggleton P, Barraclough T, Vogler AP. 2009. Accelerated species inventory on Madagascar using coalescent-based models of species delineation. Systematic Biology 58: 298-311.

Ober KA. 2002. Phylogenetic relationships of the carabid subfamily Harpalinae (Coleoptera) based on molecular sequence data. Molecular Phylogenetics and Evolution 24: 228-248.

Okutani T. 2000. Marine mollusks in Japan. Tokai University Press.

Oyama K. 1966. On living Japanese Turridae (1). Venus 25: 1-20. 
Pante E, Puillandre N, Viricel A, Arnaud-Haond S, Aurelle D, Castelin M, Chenuil A, Destombe C, Forcioli D, Valero M, Viard F, Samadi S. 2015. Species are hypotheses: avoid connectivity assessments based on pillars of sand. Molecular Ecology 24: 525544.

Pante E, Schoelinck C, Puillandre N. 2014. From integrative taxonomy to species description: one step beyond. Systematic Biology: syu083.

Perry G. 1811. Conchology, Or the Natural History of Shells: Containing a New Arrangement of the Genera Ans Species, Illustrated by Coloured Engravings, Executed from the Natural Specimens, and Including the Latest Discoveries. William Miller.

Pons J, Barraclough TG, Gomez-Zurita J, Cardoso A, Duran DP, Hazell S, Kamoun S, Sumlin WD, Vogler AP. 2006. Sequence-based species delimitation for the DNA taxonomy of undescribed insects. Systematic Biology 55: 595-609.

Poppe GT. 2008. Philippine marine mollusks Volume II. Conchbooks.

Powell AWB. 1964. The family Turridae in the indo-pacific. Part I. The subfamily Turrinae. Indo-Pacific Mollusca 1: 227-411.

Puillandre N, Lambert A, Brouillet S, Achaz G. 2012a. ABGD, Automatic Barcode Gap Discovery for primary species delimitation. Molecular Ecology 21: 1864-1877.

Puillandre N, Modica MV, Zhang Y, Sirovitch L, Boisselier MC, Cruaud C, Holford M, Samadi S. 2012b. Large scale species delimitation method for hyperdiverse groups. Molecular Ecology 21: 2671-2691.

Puillandre N, Sysoev A, Olivera BM, Couloux A, Bouchet P. 2010. Loss of planktotrophy and speciation: geographical fragmentation in the deep-water gastropod genus Bathytoma (Gastropoda, Conoidea) in the western Pacific. Systematics and Biodiversity 8: 371-394.

Rambaut A, Drummond AJ. 2014. Tracer v1.6. Available from http://beast.bio.ed.ac.uk/Tracer.

Reeve L. 1843. Monograph of the genus Pleurotoma. Conchologia Iconica 1.

Renner SS. 2016. A return to Linnaeus's focus on diagnosis, not description: The use of DNA characters in the formal naming of species. Systematic biology: syw032.

Samadi S, Barberousse A. 2009. Species: towards new, well-grounded practices. A response to Velasco. Biological Journal of the Linnean Society 96: 696-708.

Schubert G, Wagner J. 1829. Neues systematisches Conchylien-Cabinet angefangen von Martini und Chemnitz. Nürnberg, Bauer \& Raspe 12: 1-196.

Springsteen FJ, Leobrera FM. 1986. Shells of the Philippines. Carfel Seashell Museum. 
1149 Srivathsan A, Meier R. 2012. On the inappropriate use of Kimura-2-parameter (K2P)

1150 divergences in the DNA-barcoding literature. Cladistics 28: 190-194.

1151 Stamatakis A. 2006. RAxML-VI-HPC: maximum likelihood-based phylogenetic 1152 analyses with thousands of taxa and mixed models. Bioinformatics 22: 2688-2690.

1153 Tamura K, Stecher G, Peterson D, Filipski A, Kumar S. 2013. MEGA6: molecular 1154 evolutionary genetics analysis version 6.0. Molecular biology and evolution: mst197.

1155 Verbinnen G, Dirkx M. 2007. Red Sea Mollusca. Part 17. Class: Gastopoda. Family: 1156 Turridae. Gloria Maris 43: 7-27.

1157 Villanea FA, Parent CE, Kemp BM. 2016. Reviving Galápagos snails: ancient DNA 1158 extraction and amplification from shells of probably extinct Galápagos endemic land 1159 snails. Journal of Molluscan Studies: eyw011.

1160 Weinkauff H, Kobelt W. 1875-1887. Die Familie Pleurotomidae. Systematisches 1161 Conchylien-Cabinet von Martini und Chemnitz. Vol. 4.

1162 Will KP, Mishler BD, Wheeler QD. 2005. The perils of DNA Barcoding and the need 1163 for integrative taxonomy. Systematic Biology 54: 844-851.

1164 Zhang J, Kapli R, Pavlidis P, Stamatakis A. 2013. A general species delimitation 1165 method with applications to phylogenetic placments. Bioinformatics Advance Access. 


\section{Figure legends}

1168

Figure 1: Map showing the species distributions. Full squares: L. acuta; empty squares:

L. semfala; stars: L. polytropa; diamonds: L. abbreviata; hexagons: L. brevicaudata; full

1171 circles: L. picturata; empty circles: L. bratasusa; full triangles: L. jickelii; empty circles:

1172 L. kina; crosses: L. vezzaroi; black symbols: confirmed presence with sequenced material; grey symbols: presence reported in the literature or in non-sequenced material. ?: “Indian Ocean”.

1175

Figure 2: Bayesian trees (Mr. Bayes) for the COI (left) and 28S (right) genes. Posterior Probabilities ( $>0.95)$ and bootstraps values $(>75)$ are shown for each node. Letters in front of each species number refer to the locality: M: Mozambique; VN: Viet-Nam; P: Philippines; PNG: Papua New Guinea; V: Vanuatu; NC: New Caledonia.

Figure 3: Bayesian tree of the COI and 28S genes concatenated. Posterior Probabilities $(>0.95)$ and bootstraps values ( $>75)$ are shown for each node.

Figure 4: Lophiotoma acuta (Perry, 1811). - A-D. Neotype, MNHN IM-2007-41179, SL $38.8 \mathrm{~mm}$. - D. Lateral view of the protoconch. - E. Original illustration from Perry (1811). - F,G. Syntypes of Pleurotoma tigrina Lamarck, 1822 (MHNG-MOLL-51664). - F. SL 48.1 mm; - G. SL 56 mm. - H. Dark form, MNHN IM-2007-41007, SANTO2006, st. FR 10, SL 35.9 mm. - I. MNHN IM-2007-41025, SANTO2006, st. LD 01, SL 29.7 mm. - J. MNHN IM-2009-29711, Vietnam, SL 50.9 mm. - K. MNHN IM2013-10267, PAPUA NIUGINI, st. PR 07, SL 31.9 mm. - L. MNHN IM-2013-17040, PAPUA NIUGINI, st. PR 152, SL 32.5 mm. - M. MNHN IM-2013-46888, KAVIENG, st. KR 06, SL $38.2 \mathrm{~mm}$. All shells at the same scale.

Figure 5: Radulae of studied Lophiotoma. - A,B. Lophiotoma acuta (Perry, 1811). - A. MNHN IM-2013-14235. - B. MNHN IM-2013-14505. - C. Lophiotoma polytropa (Halbling, 1779), MNHN uncataloged, PANGLAO2004, st. M 50. - D. Lophiotoma brevicaudata, MNHN IM-2007-40994, SANTO 2006. - E. Lophiotoma picturata (Weinkauff, 1876), MNHN IM-2013-53422, KAVIENG, st. KZ 02, SL 24.5 mm. - F. 
Lophiotoma bratasusa sp. n., holotype, MNHN IM-2013-54124. - G. Lophiotoma jickelii (Weinkauff, 1875), neotype, MNHN IM-2013-13275. - H. Lophiotoma semfala sp. n., MNHN IM-2013-14504. - I. Lophiotoma kina sp. n., holotype, MNHN IM-201316307. Scale bars $50 \mu \mathrm{m}$.

Figure 6: Anal sinus and spiral sculpture of different species of Lophiotoma. - A. Lophiotoma acuta (Perry, 1811), MNHN IM-2007-41179. - B. Lophiotoma acuta, MNHN IM-2009-29711, SL 50-9 mm. - C. Lophiotoma semafala sp. n., holotype, MNHN IM-2007-41337, SL 41.8 mm. - D. Lophiotoma semafala sp. n., dark form, MNHN IM-2007-40830, SL 35.7 mm. - E. Lophiotoma kina sp. n., holotype, MNHN IM-2013-16307, SL 31.0 mm. - F. Lophiotoma jickelii (Weinkauff, 1875), neotype, MNHN IM-2013-13275, SL 39.4 mm. Arrows indicate diagnostic details of the sculpture.

Figure 7: Lophiotoma semfala sp. n. - A-C. Holotype, MNHN IM-2007-41337, SL 41.8 mm. -D. MNHN IM-2013-14504, PAPUA NIUGINI, st. PD 41, SL 29.5 mm. - E. MNHN IM-2007-40830, Philippines, PANGLAO 2004, st. R 62, SL 35.7 mm. - F,G. Dark form, MNHN IM-2013-04019, PAPUA NIUGINI, st. PD 39, SL 12.4 mm (F - at the same scale as other shells, F' enlarged). - G. Lateral view of the protoconch. - H. MNHN IM-2013-14965, PAPUA NIUGINI, st. PD 45, SL 26.8 mm. All shells (except $\left.F^{\prime}\right)$ at the same scale.

Figure 8: Scatterplot of protoconch measurements in studied species of Lophiotoma. D: protoconch diameter, mm; H: exposed height, mm. - A. Diamonds: L. semfala; squares: L. acuta; triangles: L. kina; circles: L. jickelii. - B. Diamonds: L. bratasusa; squares: L. picturata.

Figure 9: Shells of examined species of Lophiotoma. - A,B. Lophiotoma brevicaudata (Reeve, 1843). - A. MNHN IM-2007-40994, SANTO 2006, st. DB12, 15³6'38.0412"S; 167¹0'3.558"E, 10-18 m, SL 16,7 mm. - B. MNHN IM-2013-47803 KAVIENG 2014, st. KS15 241'14.3988"S; 15041'14.5608"E, 3-5 m, SL 26,0 mm. - C,D. Lophiotoma abbreviata (Reeve, 1843). - C. MNHN IM-2013-55783, New Caledonia, Nouméa, 
1231

1232

1233

1234

1235

1236

1237

1238

1239

1240

1241

1242

1243

1244

1245

1246

1247

1248

1249

1250

1251

1252

1253

1254

1255

1256

1257

1258

1259

1260

1261

1262

Phare Amédée, depths not documented, SL 22,4 mm. - D. MNHN IM-2007-41197, SANTO 2006, st. FB52, 1542'42.3576"S; 167²15'5.5188"E, 7 m, SL 15,8 mm. - E. Lophiotoma polytropa (Helbling, 1779), MNHN IM-2007-40832, PANGLAO 2004, st. M30, 943'5.988"N ; 12351'29.988"E, intertidal, SL 43,0 mm. - F,G. Lophiotoma vezzaroi Cosisgnani, 2015. - F. MNHN IM-2007-40983, SANTO 2006, st. DS04, 15³1'26.2776"S; 167²14'6.7956"E, 25 m, SL 14,4 mm. - G. radula voucher, Tinina Balut Island, Philippines, SL $34.7 \mathrm{~mm}$.

Figure 10: - A-F. Lophiotoma picturata (Wienkauff, 1876). - G-L. Lophiotoma bratasusa sp. n. - A,B. Lectotype of Pleurotoma picturata ZMB Moll 112610, SL 41 mm. - C-E. MNHN IM-2013-53422, Papua New Guinea, SL 24.5 mm. - E. Lateral view of the protoconch. - F. MNHN IM-2013-51988, Papua New Guinea, Kavieng Lagoon, SL 30,3 mm. - G-I. Lophiotoma bratasusa sp. n. Holotype, MNHN IM-201351244, Papua New Guinea, Kavieng Lagoon, SL 26.0 mm. - J. MNHN IM-2013-15844, Papua New Guinea, Madang Lagoon, SL 30,5 mm. - K. MNHN IM-2007-41339, Vanuatu, SL 28,2 mm. L. MNHN IM-2007-41132, Vanuatu, SL 23.8 mm.

Figure 11: Lophiotoma jickelii (Weinkauff, 1875). - A-D. Neotype, MNHN IM-201313275. - D. Lateral view of the protoconch. - E. MNHN IM-2013-54874, Papua New Guinea, Kavieng Lagoon, SL 36.2 mm. - F. MNHN IM-2007-41003, Vanuatu, 33.8 mm. - G. MNHN IM-2013-11537, Papua New Guinea, Madang Lagoon, SL 33.3 mm. H. MNHN IM-2007-41144, Vanuatu, 35.0 mm. - I. MNHN IM-2007-41182 Vanuatu, SL 32.9 mm. - J. MNHN IM-2009-7080, Mozambique, SL 29.4 mm. - K. MNHN IM2009-29713, Vietnam, SL 44.9 mm. - L. MNHN IM-2013-12760, Papua New Guinea, Madang Lagoon, SL 37.9 mm. - M,N. Original illustration of the species (Weinkauff, 1875: pl. 4, figs 2, 3). - O. Specimen from Egypt, Brother Island, 10-35 m (collection of P. Stahlshmidt). All shells (except M-N) at the same scale.

Figure 12: Lophiotoma kina sp. n. - A-C. Holotype, MNHN IM-2013-16307, SL 31.0 mm. - D. MNHN IM-2013-13278, Papua New Guinea, Madang Lagoon, SL 27.2 mm. E. MNHN IM-2009-16927, Vanuatu, SL 23.8 mm. - F. MNHN IM-2013-51209, Papua New Guinea, Kavieng Lagoon, SL 25.4 mm. - G,H. MNHN IM-2013-12950, Papua 
1263 New Guinea, Madang Lagoon, SL 20.3 mm. - H. Lateral view of the protoconch. All 1264 shells at the same scale. 


\begin{tabular}{|c|c|c|c|c|c|c|c|c|c|c|c|c|c|c|c|c|c|c|c|c|c|c|c|c|c|c|}
\hline \multirow{3}{*}{ species } & \multirow{3}{*}{$\begin{array}{c}\# \\
\text { col }\end{array}$} & \multirow{3}{*}{$\begin{array}{c}\# \\
285\end{array}$} & \multirow{3}{*}{$\begin{array}{c}\# \\
\mathrm{COI}+28 \mathrm{~S}\end{array}$} & \multicolumn{4}{|c|}{ col } & \multicolumn{2}{|c|}{285} & \multicolumn{4}{|c|}{$\mathrm{COl}+28 \mathrm{~S}$} & & & & & & & & & & & & & \\
\hline & & & & \multicolumn{2}{|c|}{ ABGD } & \multirow{2}{*}{\begin{tabular}{|c|} 
GMYC \\
\cline { 1 - 2 } simple
\end{tabular}} & \multirow{2}{*}{ PTP } & \multirow{2}{*}{ ABGD } & \multirow{2}{*}{ PTP } & \multicolumn{2}{|c|}{ ABGD } & \multirow{2}{*}{\begin{tabular}{|c|} 
GMYC \\
\cline { 1 - 2 }
\end{tabular}} & \multirow{2}{*}{ PTP } & \multicolumn{6}{|c|}{ Monophyly (PP/B) } & \multirow{2}{*}{ Bathymetry } & \multicolumn{6}{|c|}{ Geography } \\
\hline & & & & lumper & splitter & & & & & lumper & splitter & & & \multicolumn{2}{|c|}{ col } & \multicolumn{2}{|c|}{285} & \multicolumn{2}{|c|}{$\mathrm{COI}+28 \mathrm{~S}$} & & $\mathbf{M}$ & vN & \multirow{2}{*}{\multicolumn{2}{|c|}{\begin{tabular}{l|l}
$\mathbf{P}$ & PNG \\
$x$ &
\end{tabular}}} & \multirow[t]{2}{*}{\begin{tabular}{l|l}
$V$ & $N$ \\
\end{tabular}} & \\
\hline polytropa & 6 & 6 & 5 & & & & & & & & & & & $1 / 92$ & & $1 / 92$ & & $1 / 95$ & & 1-3 m. & & & & & & \\
\hline abbreviata & 13 & 8 & 5 & & & & 3 groups & & & & & & & & $-1-$ & & $0,95 / 62$ & & $0,93 / 95$ & $0-7 \mathrm{~m}$. & & & s & \begin{tabular}{l|l}
$x$ & $x$
\end{tabular} & \begin{tabular}{l|l}
$x$ & $x$ \\
\end{tabular} & \\
\hline brevicaudata & 24 & 19 & 6 & & & & & & & & & & & | & $0,99 / 77$ & $0,9 / 01$ & - & $1 / 100$ & $0,7 / 59$ & $2-38 \mathrm{~m}$ & & & $\mathrm{x}$ & \begin{tabular}{l|l}
$x$ & $x$
\end{tabular} & $\mathrm{x}$ & \\
\hline picturata 1 & 2 & 1 & 1 & & & & & & & & & & & & $1 / 100$ & & na & & na & 7-22 m. & & & & $x$ & & \\
\hline picturata 2 & 6 & 3 & 3 & & & & & & & & & & & $1 / 100$ & $1 / 74$ & $0,96 / 64$ & - & $1 / 100$ & $0,97 / 90$ & $3-42 \mathrm{~m}$. & & & & $x$ & & \\
\hline bratasusa & 22 & 15 & 7 & & & & & & & & & & & $1 / 100$ & & & $0,95 / 61$ & $1 / 100$ & & $0-35 \mathrm{~m}$. & & & & \begin{tabular}{l|l}
$x$ & $x$
\end{tabular} & $x$ & \\
\hline jickelii 1 & 28 & 11 & 9 & & & & & & & & & & & 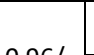 & $0,95 /-$ & 1 & - & & $0,98 / 80$ & $1-22 \mathrm{~m}$. & $x$ & $x$ & $\mathrm{x}$ & & & \\
\hline jickelii 2 & 5 & 4 & 4 & & & & & & & & & & & 0,90/- & $1 / 59$ & 7 & - & $1 / 91$ & $1 / 89$ & $1-40 \mathrm{~m}$. & & & & \begin{tabular}{l|l}
$x$ & $x$
\end{tabular} & $\mathrm{x}$ & \\
\hline acuta 1 & 96 & 87 & 10 & & & & & & & & & & & $1 / 06$ & $0,93 / 65$ & $1 / 07$ & - & $1 / 120$ & $0,89 / 86$ & $0-22 \mathrm{~m}$ & & & & & $x$ & \\
\hline acuta 2 & 60 & 17 & 12 & & & & & & & & & & & $1 / 96$ & - & $1 / 82$ & - & $1 / 100$ & - & 0-99 m. & & $x$ & $\mathrm{x}$ & \begin{tabular}{l|l}
$x$ & $x$
\end{tabular} & $\mathrm{x}$ & \\
\hline semfala 1 & 5 & 2 & 2 & & & & & & & & & & & 1100 & na & 000/06 & - & $1 / 100$ & $1 / 88$ & $2-15 \mathrm{~m}$ & & & & \begin{tabular}{l|l}
$x$ & $x$ \\
\end{tabular} & $x$ & \\
\hline semfala 2 & 1 & 1 & 1 & & & & & & & & & & & $1 / 100$ & $1 / 89$ & טכוכי, & na & $1 / 100$ & na & 2-99 m. & & & $\mathrm{x}$ & & & \\
\hline vezzaroi & 3 & 2 & 2 & & & & & & & & & & & $1 / 99$ & & $1 / 96$ & & $1 / 100$ & & $15-30 \mathrm{~m}$ & & & & & $\mathrm{x}$ & \\
\hline kina 1 & 4 & 4 & 3 & & & & & & & & & & & 7ח & $0,98 / 83$ & 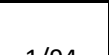 & - & 100 & $0,9 /-$ & no data & & & & $x$ & & \\
\hline kina 2 & 1 & 1 & 1 & & & & & & & & & & & $1 / 97$ & na & $1 / 94$ & na & $1 / 99$ & na & 3-15 m. & & & & & $\mathrm{x}$ & \\
\hline
\end{tabular}

Table 1: Results of the integrative species delimitation approach. For each group defined with at least one method, the species name as defined ultimately, the number of specimens sequenced in each dataset, the results of the three species delimitation methods (ABGD, GMYC and PTP ${ }^{\circ}$ for the three datasets, the monophyly (with Posterior Probabilities/Bootstrap support) as assessed with each dataset, and the bathymetric and geographic distributions are provided from left to right. Na: non applicable; M: Madagascar; VN: Viet-Nam; P: Philippines; PNG: Papua New-Guini; V: Vanuatu; NC: New Caledonia. 
Table 2. List of diagnostic sites (character state - position) for both COI and 28S gene for each species

277

species

L. polytropa

L. abbreviata

L. brevicaudata

L. jickelii

L. picturata

L. bratasusa n. sp.

L. vezzaroi

L. kina n. sp.

L. semfala n. sp.
COI

T - 290; G - 292; C - 334; A - 376; C - 424; G - 553

$$
G-331
$$

G - 535

C - 158; A - 313; C - 457; T - 598

C - 100; G - 181; T - 508; C - 529; C - 538

C - 151; G - 211; C - 238; C - 451

G - 37; C - 92; C - 259; C - 271; C - 347; T- 418; C - 533; T - 562

A - 22; G - 232; G - 574; C - 613

C -74; A - 85; T - 127; G - 208; T - 295; C - 307; C - 319; C - 328; C -

428
285

A - 854; T -860

C - 396

G - 858

C -833

T - 541; A - 680; A - 696

C - 404; T - 855; G - 860 $\mathrm{T}-496$ 
1280

1281 Supplementary Material 1: List of specimens analyzed, with MNHN number, species name, geographic locality, depth, and BOLD and GenBank accession numbers. 


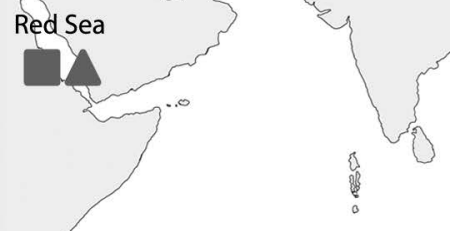

$\because 8$.

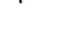

\section{Mozambique}

$\triangle$

?

Madagascar

South Africa
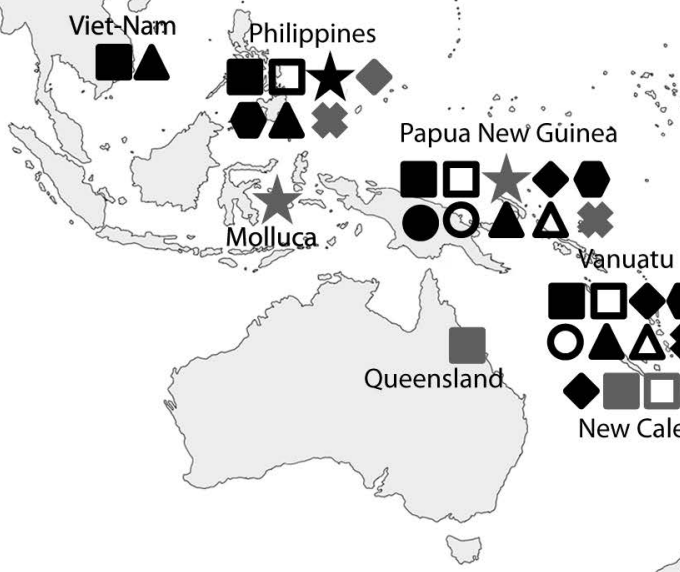

DO Fiji. $0 \Delta \Delta \sim$ $\checkmark \square$ New Caledonia

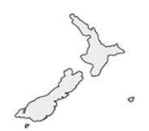




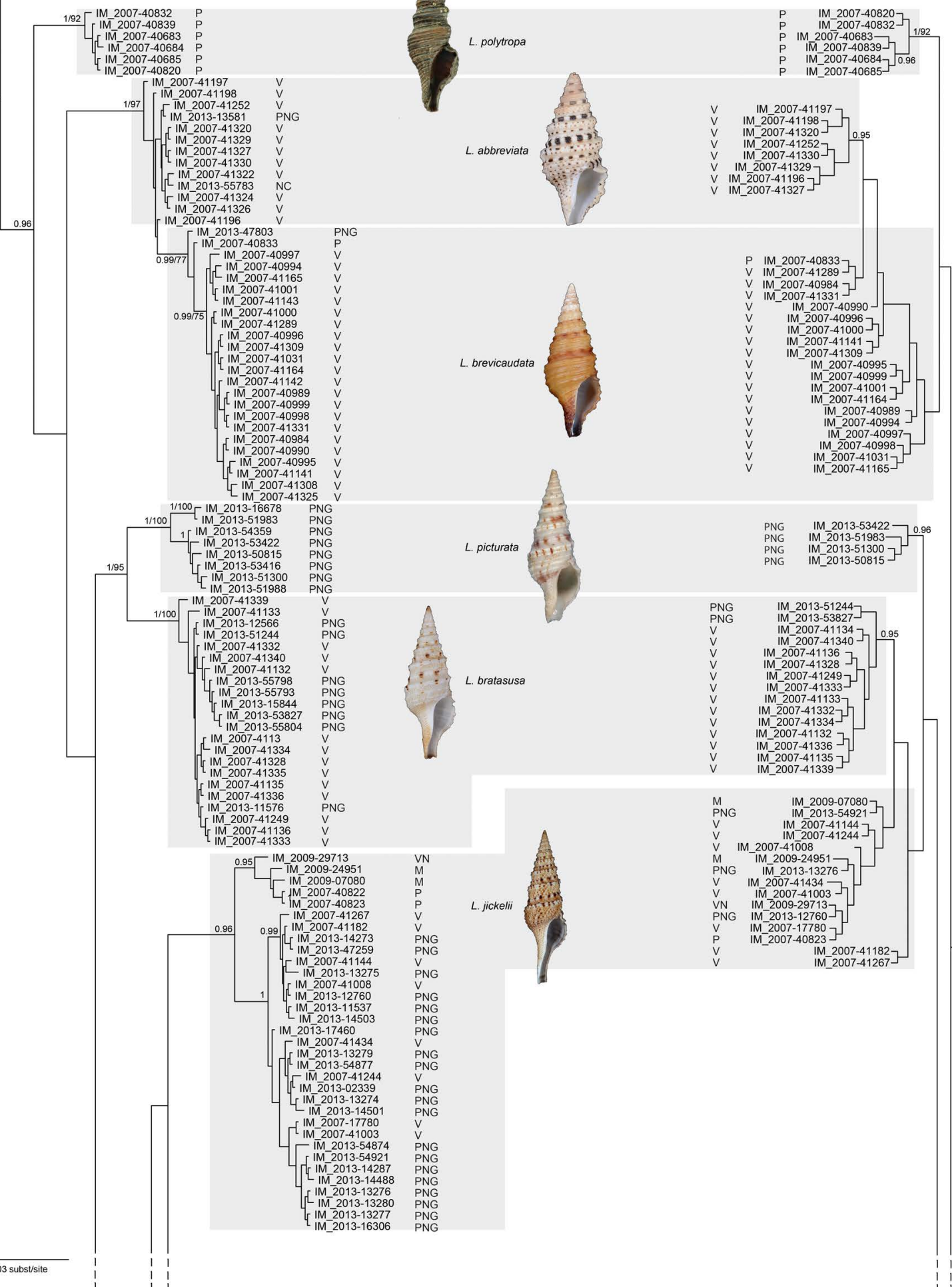




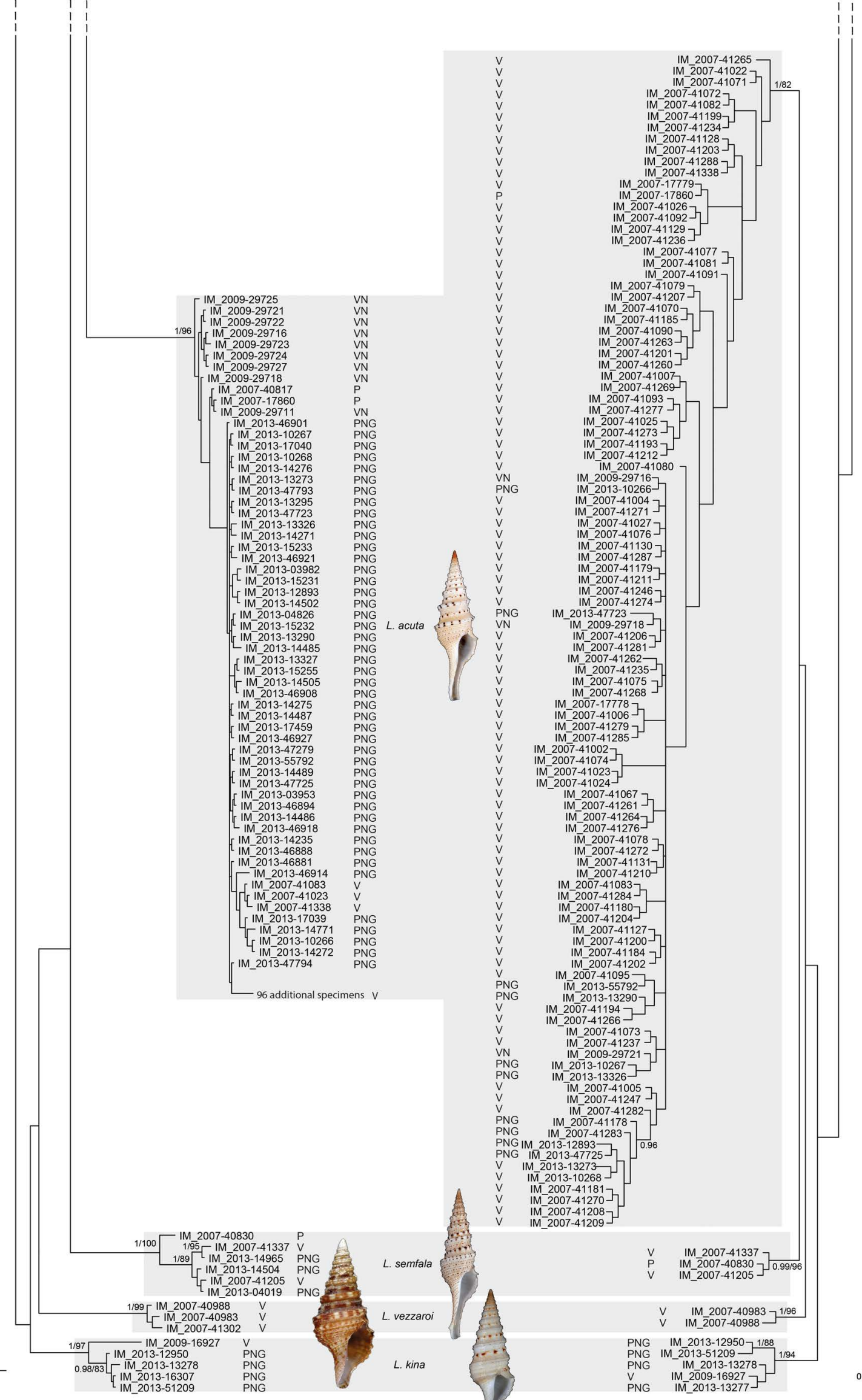




\section{/I IM_2007-16735 Terebra cingulifera}

IM_2007-17756 Lophiotoma albina $1 / 95$ [ IM_2007-40832

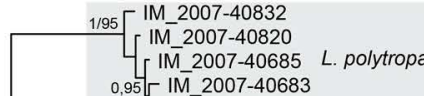

$0,95[$ IM_2007-40683

- IM_2007-41197 [IM_2007-41197

IM_2007-41320 L. abbreviata

[ IM_2007-41252

L IM_2007-41327

$1 / 94$

IM_2007-40833

IM 2007-41289

[L IM_2007-41331

IIM_2007-41001

L. brevicaudata

[ IM_2007-41141

981 _ IM_2009-29713

[IM_2009-2495

IIM_2007-40823

1 L IM_2009-07080

IM_2013-12760

[ IM_2007-41144

$1 / 89$

[ IM_2007-41182

L. jickelii

CIM_2007-41244

L IM-2007-41434

IM_2013-54921

1/88 [ IM_2013-13276

_IM 2013-13277

1/100 _ IM_2013-51983

1/100 IM-2013-50815

0,97/90 [ IM_2013-51300

L. picturata

- IM 2007-41339

1/100 IM_2007-41132

II IM_2013-51244

LIM $[$ 2013-53827 L. bratasusa IM 2007-41328

[IM_2007-41136

0,95/77 IM_2007-41249

1/100 [ IM_2007-40983

IM_2007-40988

L. vezzaroi

IM_2009-16927

1/99 _IM_2013-13278

[IM_2013-12950

IM_2013-51209 1/100 [ IM_2007-40830

L. kina

1/88 IM_2007-41205 L. semfala

IM_2007-41337

IM 2009-29716

[I IM_2009-29718

$1 / 100$

$\mathrm{IM}^{-}$

IM_2013-13290

II IM 2013-47723

IM_2013-55792

- IM 2013-13326

IM_2013-13273

[ IM_2013-47725

IM_2013-10268

[ IM_2013-12893

L. acuta

IM 2007-41024

186 IM_2007-41073

6 IM-2007-41194

IIM_2007-41067

IM_2007-41287

IM 2007-41007

[ IM_2007-41090

IM 2007-41199
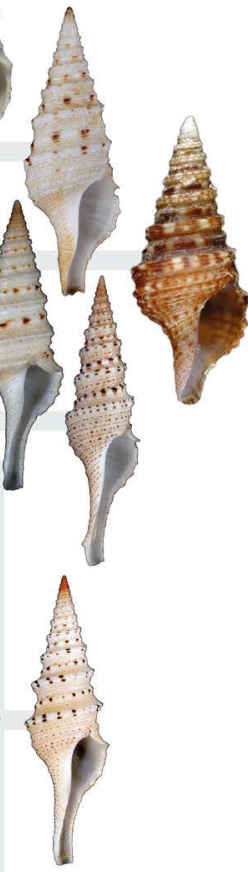


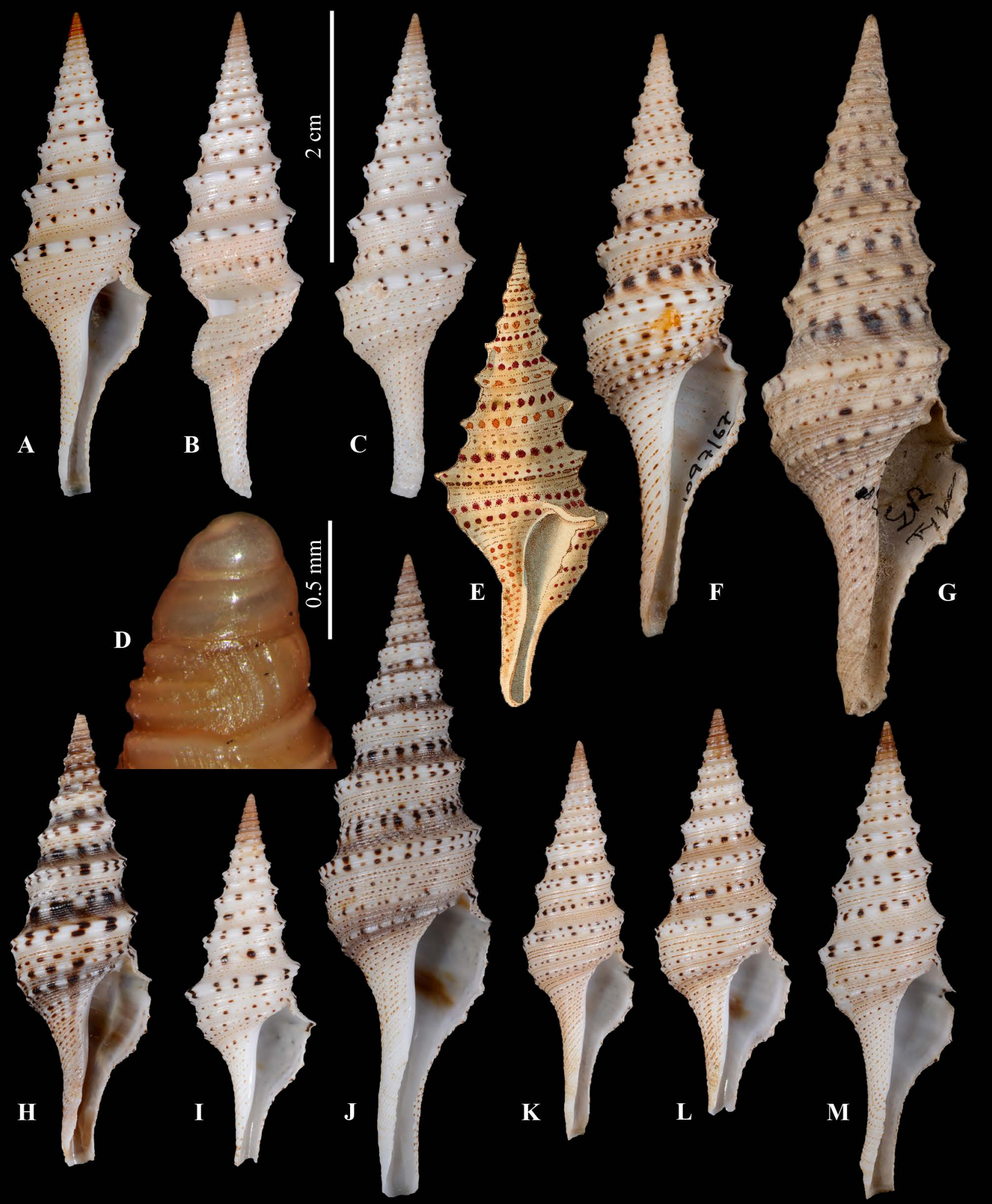




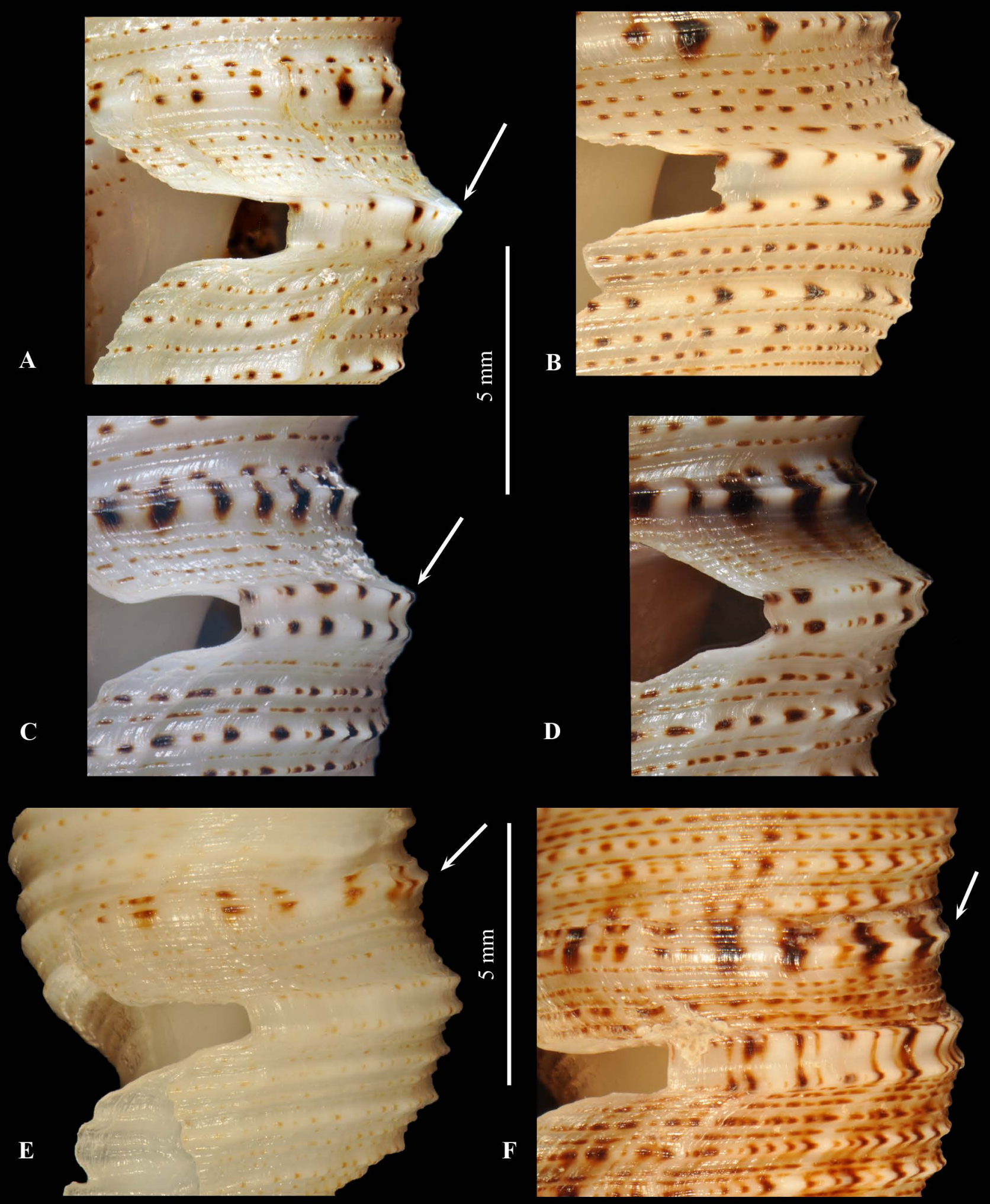




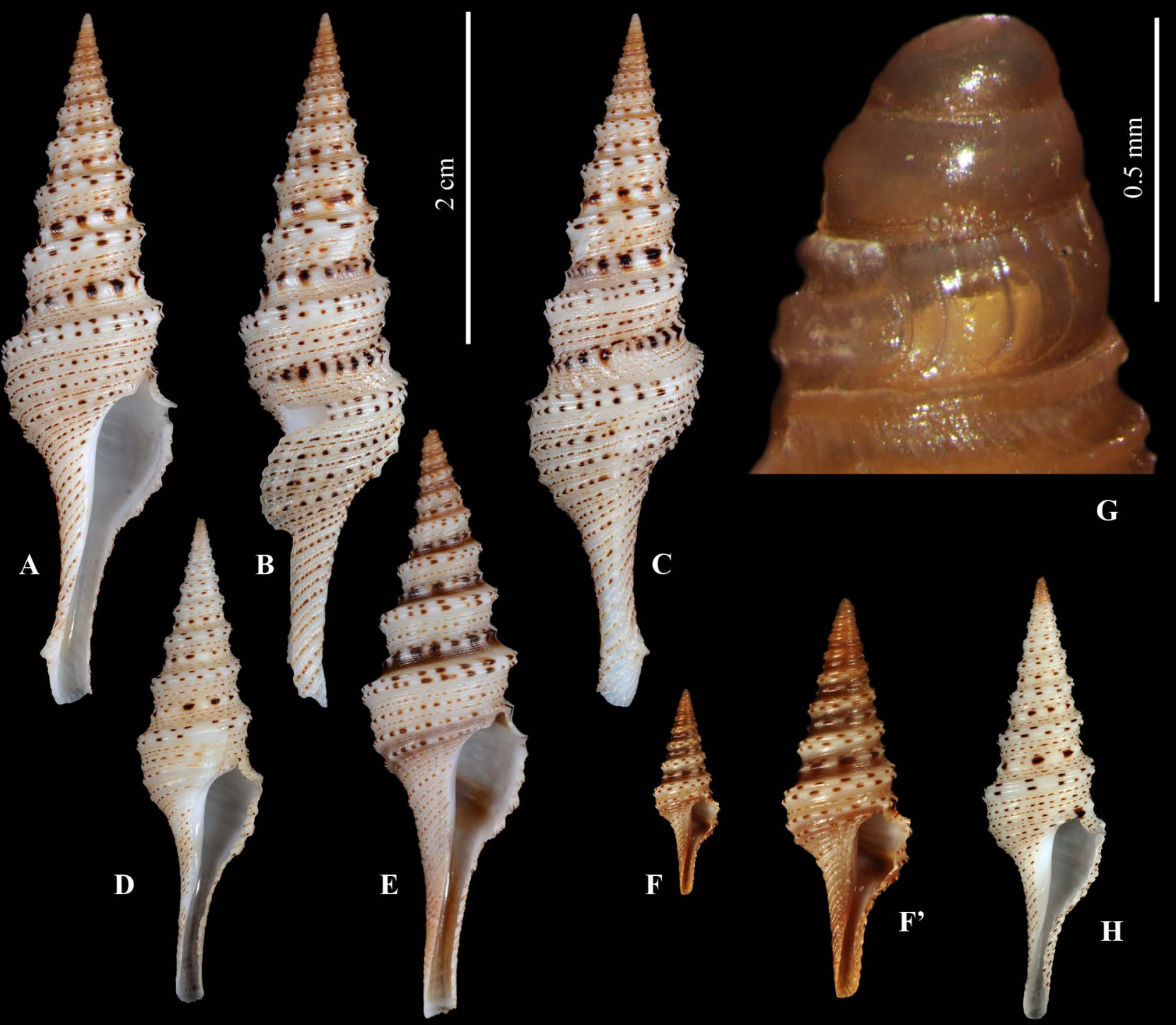




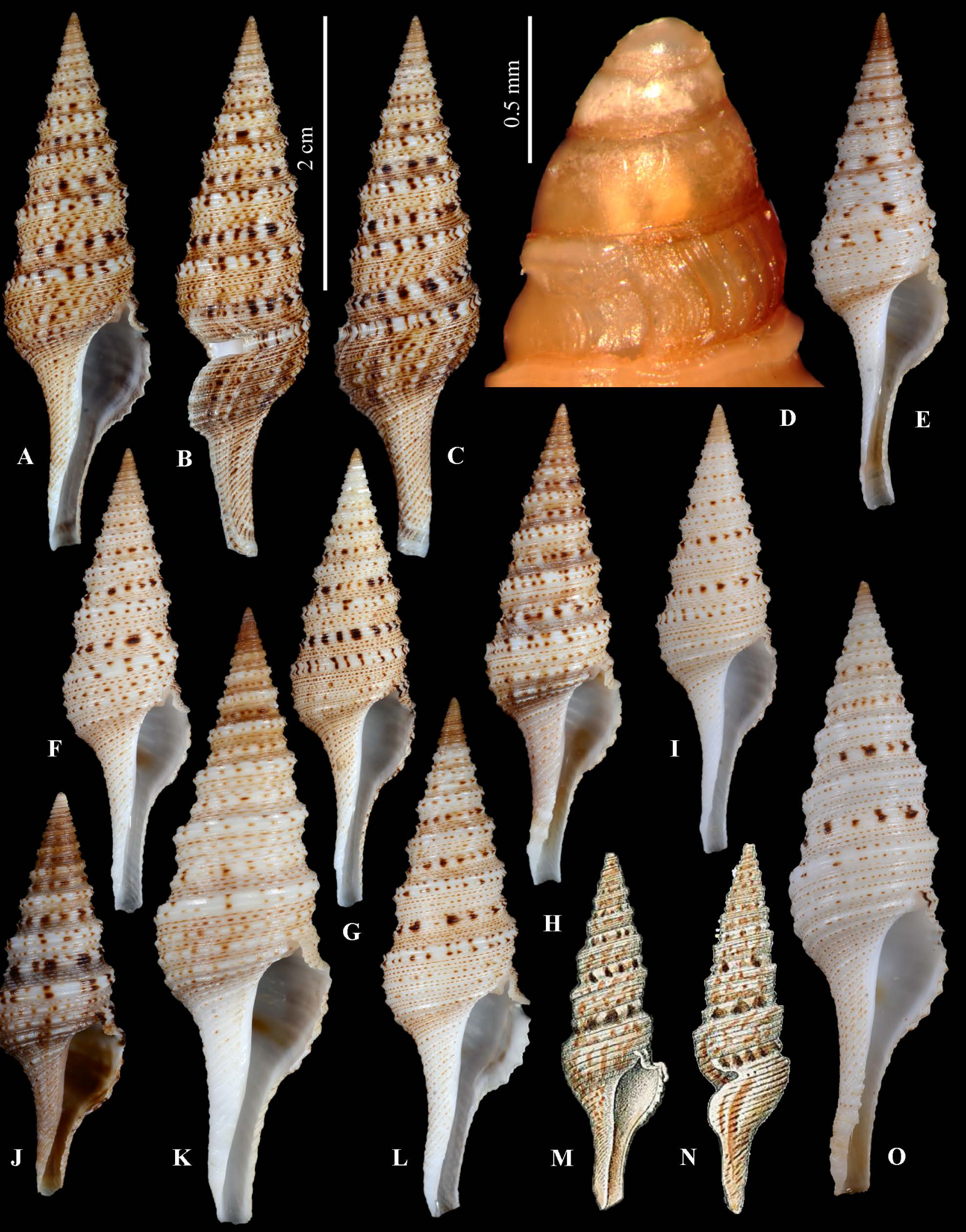




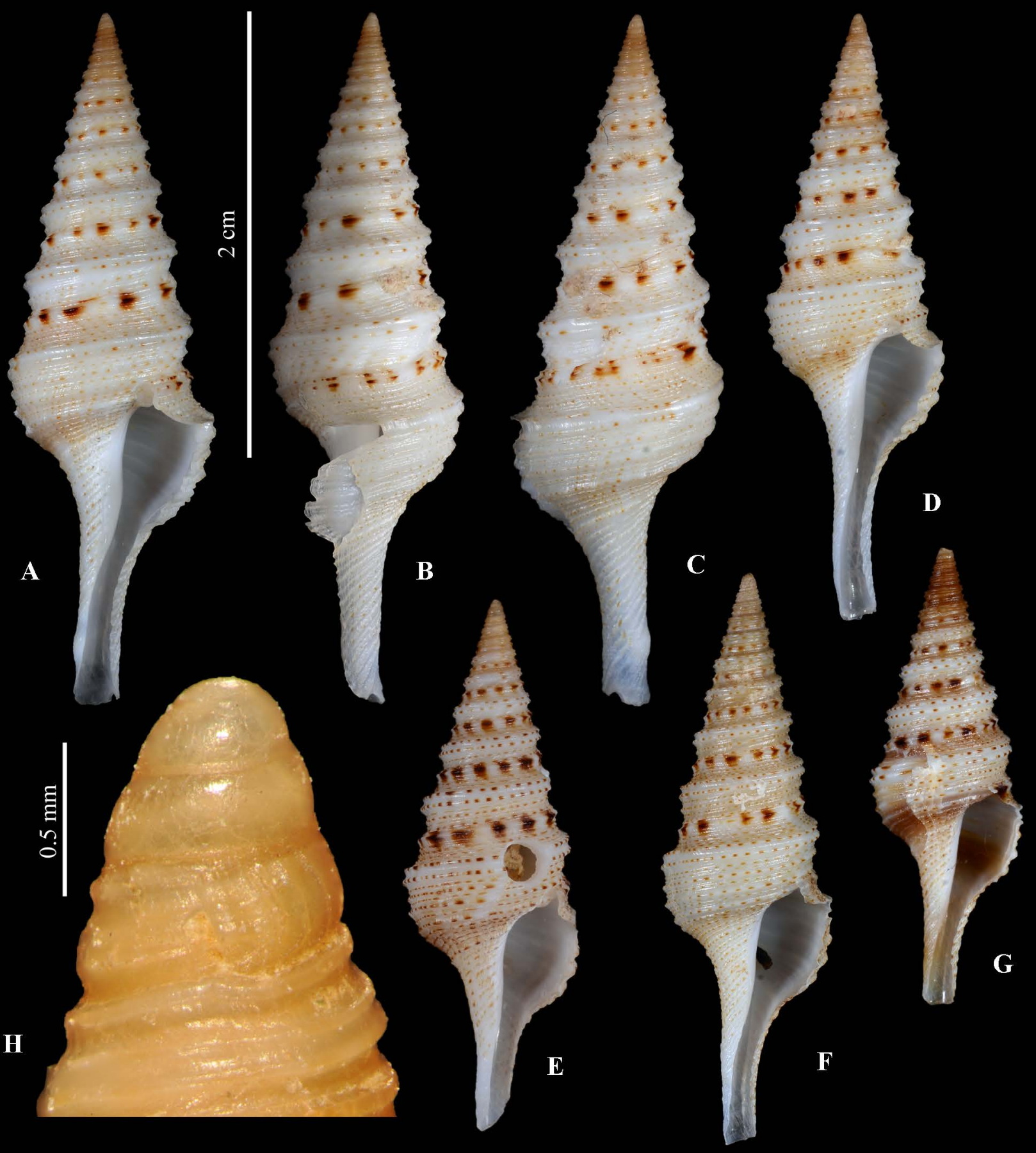

